\title{
Cementos petroleros con adición de escoria de horno alto. Características y propiedades
}

\section{Characteristics and properties of oil-well cements additioned with blast furnace slag}

\author{
R. Sánchez ${ }^{(*)}$, M. Palacios ${ }^{(* *)(* * *)}, \underline{\text { F. Puertas }}^{(* * *)}$
}

Recepción/Received: 25-VIII-09

Aceptación/Accepted: 4-VIII-10

Publicado online/Online publishing: 20-X-10

RESUMEN

En el presente trabajo se ha estudiado la activación alcalina de cementos Pórtland con incorporación de escoria de horno alto ( $20 \%$ y $30 \%$ con respecto al peso de cemento) para su posible aplicación en la cementación de pozos petrolíferos.

Los estudios de hidratación realizados indican que en mezclas cemento/escoria, la disolución activadora de silicato sódico inhibe parcialmente la disolución de las fases silicato del cemento Pórtland originando un retraso de su hidratación así como la menor precipitación de productos de reacción. Dicha parcial inhibición de los procesos reactivos en las mezclas cemento/escoria originan resistencias mecánicas significativamente inferiores a las pastas de cemento Pórtland hidratadas con agua. Finalmente, los estudios de ${ }^{29} \mathrm{Si}$ y ${ }^{27} \mathrm{Al}$ RMN MAS y BSE/EDX indican que el gel C-S-H formado en pastas de mezcla cemento/escoria activadas alcalinamente presenta Al en posiciones tetraédricas y bajas relaciones $\mathrm{Ca} / \mathrm{Si}$.

Palabras clave: activación alcalina, escorias de horno alto, hidratación, microestructura, cementos petroleros.
SUMMARY

The present paper addresses the alkali activation of Portland cements containing blast furnace slag (20 and $30 \%$ by cement weight) with a view to the possible use of these materials in oil well construction.

The hydration studies conducted showed that in cement/slag blends, the sodium silicate activator partially inhibited the dissolution of the silicate phases in the Portland cement, retarding cement hydration and reducing the precipitation of reaction products. Due to such partial inhibition, the cement/slag blends had significantly lower mechanical strength than Portland cements hydrated with water. ${ }^{29} \mathrm{Si}$ and ${ }^{27} \mathrm{Al}$ MAS NMR and BSE/EDX studies, in turn, showed that the CSH gel forming in the alkali-activated cement/slag pastes contained $\mathrm{Al}$ in tetrahedral positions and low Ca/Si ratios.

Keywords: alkali activation, blast furnace slag, hydration, microstructure, oil-well cements.

(*) ESIQIE IPN Zacatenco (México).

(**) Institute of Building Materials, ETH Zurich (Switzerland).

(***) Instituto de Ciencias de la Construcción Eduardo Torroja (IETcc-CSIC) (Madrid, España). 


\section{INTRODUCCIÓN}

Las severas condiciones de operación de los pozos petrolíferos (profundidades de hasta $9.000 \mathrm{~m}$, temperaturas de $260{ }^{\circ} \mathrm{C}$ y presiones alrededor de $200 \mathrm{MPa}$ ) requieren que los cementos utilizados tengan características químicas y físicas muy específicas (1). La API (American Petroleum Institute) establece 8 clases de cemento petrolero de la $\mathrm{A}$ a la $\mathrm{H}$. Su principal diferencia estriba en su contenido de $\mathrm{C}_{3} \mathrm{~A}$ y pueden ser ordinarios, de moderada o alta resistencia a los sulfatos, lo que determina la profundidad a la que pueden emplearse. Los cementos utilizados a mayores profundidades y en medios más agresivos son los tipo $\mathrm{G}$ y $\mathrm{H}$, los cuales tienen una composición química muy parecida y sólo se diferencian entre sí por su superficie específica de $280-340 \mathrm{~m}^{2} / \mathrm{kg}$ y $200-260 \mathrm{~m}^{2} / \mathrm{kg}$, respectivamente $(2,3)$.

Para su colocación en el pozo petrolero se prepara una lechada de cemento, la cual debe permanecer suficientemente móvil durante el bombeo y una vez colocada debe desarrollar rápidamente una resistencia mecánica apropiada para impedir la comunicación de fluidos desde la formación al pozo. El diseño de cada lechada es único en cada caso, ya que éste depende de las condiciones del pozo petrolero y de los aditivos empleados (4). La eliminación efectiva de los lodos de perforación y el efecto de la contaminación de la lechada por los lodos de perforación o los lodos de lavado son dos de las variables más importantes que determinan el éxito del aislamiento zonal desarrollado por la capa de cemento. Sin embargo, garantizar estas condiciones es casi imposible (5).

Innovaciones en los procesos de cementación de pozos petroleros ha llevado a la utilización de escoria de alto horno para contrarrestar los problemas surgidos durante la cementación de pozos horizontales, minimizando los problemas de recirculación y facilitando la operación tradicional (6-9). Algunos trabajos indican que la utilización de un fluido de perforación universal que contenga escoria granulada de alto horno como adición (entre un 25 y un $35 \%$ ); además del empleo de lechadas de cemento con un porcentaje de reemplazo variable de escoria granulada (entre un 20 y un 40\%) (6-9) han sido casos exitosos. Hasta ahora los esfuerzos se han enfocado en la optimización de esta tecnología pero poco se ha hecho por la comprensión de los procesos de hidratación que ocurren en las lechadas de cemento con reemplazo de escoria y por la evolución de sus resistencias mecánicas.

La escoria vítrea granulada de horno alto es un subproducto de la industria siderúrgica, que posee propiedades hidráulicas. En el sector de la construcción, el empleo de dicha escoria permite obtener cementos más eco-eficientes que el cemento Pórtland, ya que su fabricación

\section{INTRODUCTION}

The harsh operating conditions that prevail in oil wells (depths of up to $9000 \mathrm{~m}$, temperatures of $260{ }^{\circ} \mathrm{C}$ and pressures of around $200 \mathrm{MPa}$ ) call for cements with very specific chemical and physical characteristics (1). The American Petroleum Institute (API) identifies eight classes of oil-well cement, $A$ to $H$, that differ primarily in their $C_{3} A$ content and their sulphate resistance (standard, moderate or high), which determines the depth at which they may be used. Classes $G$ and $H$ are the cements used at the greatest depths and in the most aggressive environments The chemical composition of these two cements is similar, although their specific surface differs: $280-340 \mathrm{~m}^{2} / \mathrm{kg}$ in the former and 200$260 \mathrm{~m}^{2} / \mathrm{kg}$ in the latter $(2,3)$.

Cement slurries that are to be poured into oil wells must remain sufficiently fluid during pumping operations, but once in place must rapidly develop the necessary mechanical strength to prevent formation fluids from flowing into the well. Slurry design is unique to each case and depends on oil well conditions and the admixtures used (4). The efficient elimination of drilling sludge and the effect of slurry contamination by drilling or cleaning sludge are two of the most important variables that determine whether the layer of cement successfully establishes the necessary separation. Guaranteeing these conditions is nearly impossible, however (5).

Innovations in oil well cementing have included the use of blast furnace slag to counter the problems arising during horizontal well cementing. This has minimised recirculation problems and facilitated traditional well operation (6-9). A number of authors have proposed the use of a universal drilling fluid containing granulated blast furnace slag as an addition (at rates of from 25 to $35 \%$ ). Cement slurries with a variable replacement ratio of granulated slag (from 20 to $40 \%$ ) have also been successfully applied (6-9). To date efforts have focused on optimising this technology, but little has been done to understand hydration processes or strength development in slag-containing cement slurries.

Vitreous blast furnace slag, a iron industry by-product, exhibits hydraulic properties. In construction, slag has proven to be a more eco-efficient binder than Portland cement, inasmuch as its manufacture entails lower energy and greenhouse gas emissions. On the one hand, 
conlleva menores consumos energéticos y menores emisiones a la atmósfera de gases causantes del efecto invernadero. Por un lado, la escoria se utiliza habitualmente como un sustituto parcial del clínker del cemento en los cementos de escoria. Por otro lado, también es posible obtener cementos carentes de clínker Pórtland mediante la mezcla de escoria con una disolución fuertemente alcalina.

En ambos casos, los procesos de hidratación así como la naturaleza y estructura de los productos de reacción han sido estudiados en profundidad (10-14). Estos dos tipos de cementos se caracterizan por presentar bajos calores de hidratación, buenas propiedades durables y elevadas resistencias a largas edades de curado. Sin embargo, únicamente los cementos de escoria activada alcalinamente presentan altas resistencias mecánicas a cortas edades de curado, siendo mayores cuando se utiliza silicato sódico como disolución activadora (15).

Si bien existen numerosos trabajos sobre cementos de escorias así como cementos de escoria activada alcalinamente, hasta la fecha son muy pocos las investigaciones realizadas sobre cementos que conjugan los dos conceptos, es decir, sobre cementos con adición de escoria activados con una disolución alcalina y concretamente, no existe ningún estudio en torno a la activación alcalina de cementos petroleros con adición de escoria.

Por lo tanto, el objetivo del presente trabajo es estudiar el proceso de activación de cementos petroleros con adición de escoria $(20 \%$ y $30 \%$ con respecto al peso de cemento), así como su microestructura y su impacto en la evolución de sus propiedades mecánicas. El presente trabajo ha sido realizado en condiciones normales de laboratorio, siendo este estudio necesario para conocer el efecto de la disolución alcalina sobre los cementos de escoria sin interferencia de las condiciones extremas de presión y temperatura que se producen en un pozo de petróleo.

\section{EXPERIMENTAL}

\subsection{Materiales}

El cemento $\mathrm{H}$ fue proporcionado por Holcim Apasco S.A. de C.V. y la escoria por Altos Hornos de México S. A. de C.V. Su composición química se determinó de acuerdo a la norma UNE EN 196-2:2006 (16) y se presenta en la Tabla 1. La composición mineralógica del cemento $\mathrm{H}$ se calculó de acuerdo a Bogue y a la norma API SPEC 10A, y se muestra en la Tabla 2. La escoria se molió hasta obtener una superficie específica Blaine de $320 \mathrm{~m}^{2} / \mathrm{kg}$. El cemento tiene una superficie específica Blaine de $280 \mathrm{~m}^{2} / \mathrm{kg}$. slag is routinely used as a partial replacement for cement clinker in slag cements. On the other, completely Portland-free cements can be obtained by mixing slag with a highly alkaline solution.

The hydration process as well as the nature and structure of the reaction products have been studied in depth for these two types of cement (10-14). Both are characterised by low heat of hydration values, long durability and high strength at long curing ages. Only alkali-activated slag cement exhibits high early age mechanical strength, however, in particular when sodium silicate is used as the activating solution (15).

While any number of papers have been published on slag-cement blends and alkali-activated slag cement, to date very few studies have been conducted on combinations of the two, i.e., slag-additioned cements activated with an alkaline solution. More specifically, the literature contains nothing on the alkali activation of slag-additioned oil-well cement.

Consequently, the present study aims to explore slagadditioned (20-30\% cement weight) oil-well cement activation, the microstructure of the resulting material and the impact of such activation on the development of its mechanical properties. It was conducted in a normal laboratory environment to understand the effect of the alkaline solution on slag cements in the absence of the extreme pressure and temperature prevailing in oil wells.

\section{EXPERIMENTAL}

\subsection{Materials}

H-type cement was furnished by Holcim Apasco S.A de C.V. and the slag by Altos Hornos de México S.A. de C.V. Its chemical composition, determined as specified in Spanish and European standard UNE EN 196-2:2006 (16), is given in Table 1. Table 2 shows the mineralogical composition of cement $H$, which was calculated as per Bogue and API standard SPEC 10A. The slag was ground to a Blaine fineness of $320 \mathrm{~m}^{2} / \mathrm{kg}$. The Blaine fineness of the cement was $280 \mathrm{~m}^{2} / \mathrm{kg}$. 
Tabla 1 / Table 1

Composición química de los materiales empleados. Chemical composition of the materials used.

\begin{tabular}{|c|c|c|}
\hline & Cemento H / Cement $H$ [\%] & Escoria / Slag [\%] \\
\hline $\mathrm{CaO}$ & 64.80 & 35.77 \\
\hline $\mathrm{SiO}_{2}$ & 20.61 & 96.9 \\
\hline $\mathrm{Al}_{2} \mathrm{O}_{3}$ & 3.26 & 2.41 \\
\hline $\mathrm{Fe}_{2} \mathrm{O}_{3}$ & 5.31 & 9.00 \\
\hline $\mathrm{MgO}$ & 1.94 & 0.06 \\
\hline $\mathrm{SO}_{3}$ & 2.36 & 1.65 \\
\hline $\mathbf{S}^{-}$ & - & 1.08 \\
\hline $\mathrm{Na}_{2} \mathrm{O}$ & 0.51 & 1.24 \\
\hline $\mathrm{K}_{2} \mathrm{O}$ & 0.91 & 0.19 \\
\hline $\mathrm{I.R.}$ & 0.21 & 2.49 \\
\hline Lol & 1.22 & \\
\hline
\end{tabular}

Tabla 2 / Table 2

Composición mineralógica del cemento $\mathrm{H}$.

Cement H: mineralogical composition.

\begin{tabular}{|c|c|c|}
\hline Fase / Phase & BOGUE & API SPEC 10AS \\
\hline $\mathbf{C}_{3} \mathbf{S}$ & $81.30 \%$ & $72.46 \%$ \\
\hline $\mathbf{C}_{2} \mathbf{S}$ & $1.84 \%$ & $11.03 \%$ \\
\hline $\mathbf{C}_{4} \mathrm{AF}$ & $16.86 \%$ & $16.51 \%$ \\
\hline $\mathrm{C}_{3} \mathrm{~A}$ & - & - \\
\hline
\end{tabular}

§ Considera que $\% \mathrm{C}_{3} \mathrm{~A}=0$ cuando $\mathrm{Al}_{2} \mathrm{O}_{3} / \mathrm{Fe}_{2} \mathrm{O}_{3}<0,64$ / § According to which $\% \mathrm{C}_{3} \mathrm{~A}=0$ when $\mathrm{Al}_{2} \mathrm{O}_{3} / \mathrm{Fe}_{2} \mathrm{O}_{3}<0.64$.

Se prepararon mezclas de cemento Pórtland tipo $\mathrm{H}$ escoria granulada del alto horno de acuerdo a las composiciones de la Tabla 3. La relación líquido/sólido empleada en todos los casos fue de 0,42. Algunas de las lechadas se prepararon con una disolución alcalina (DA) de $\mathrm{Na}_{2} \mathrm{SiO}_{3} \cdot 9 \mathrm{H}_{2} \mathrm{O}$ al 3,5\% en masa de $\mathrm{Na}_{2} \mathrm{O}$ respecto del contenido de escoria. El silicato de sodio sólido empleado fue grado reactivo (Fermont) con un módulo $\mathrm{SiO}_{2} /$ $\mathrm{Na}_{2} \mathrm{O}$ de 0,9694 .
Type H Portland cement-granulated blast furnace slag blends were prepared in the proportions shown in Table 3. A liquid/solid ratio of 0.42 was used in all cases. Some of the slurries were prepared with an $\mathrm{Na}_{2} \mathrm{SiO}_{3} \cdot 9 \mathrm{H}_{2} \mathrm{O}$ alkaline solution ( $\mathrm{AS}$ ) ( $\mathrm{Na}_{2} \mathrm{O}=3.5 \%$ of slag mass). The Fermont reagent grade solid sodium silicate used had a $\mathrm{SiO}_{2} / \mathrm{Na}_{2} \mathrm{O}$ ratio of 0.9694 .

Tabla 3 / Table 3

Composición de las mezclas escoria-cemento preparadas. Composition of the cement-slag blends.

\begin{tabular}{|c|c|c|c|c|}
\hline \multirow{2}{*}{ Ident. } & \multirow{2}{*}{$\%$ Cemento / Cement } & \multirow{2}{*}{$\%$ Escoria / Slag } & \multicolumn{2}{|c|}{ Líquido de amasado / Mixing liquid } \\
\cline { 3 - 5 } & & & Agua / Water & +DA / + AS \\
\hline 100C-W & 100 & 0 & $\mathrm{X}$ & \\
\hline 80C20S-W & 80 & 20 & $\mathrm{X}$ & $\mathrm{X}$ \\
\hline 70C30S-W & 70 & 30 & & $\mathrm{X}$ \\
\hline 80C20S-AS & 80 & 20 & & $\mathrm{X}$ \\
\hline 70C30S-AS & 70 & 30 & & \\
\hline 100S-AS & 0 & 100 & & \\
\hline
\end{tabular}

+ DA=Disolución alcalina preparada con $\mathrm{Na}_{2} \mathrm{SiO}_{3} \cdot 9 \mathrm{H}_{2} \mathrm{O}$ al 3,5\% $\mathrm{Na}_{2} \mathrm{O}$ en base al contenido de escoria. / $+\mathrm{AS}=\mathrm{Alkaline}$ solution prepared with $\mathrm{Na}_{2} \mathrm{SiO}_{3} \cdot 9 \mathrm{H}_{2} \mathrm{O}$ containing $3.5 \% \mathrm{Na}_{2} \mathrm{O}$ (slag content). 


\subsection{Ensayos realizados}

\subsubsection{Estudios de la hidratación}

Se determinó la velocidad de evolución de calor y calor total liberado en el proceso de hidratación de los cementos mediante calorimetría isoterma de conducción en un equipo Thermometric TAM Air. Se pesaron $5 \mathrm{~g}$ de cada cemento y se mezclaron con agua descarbonatada y/o disolución activadora, según fue el caso, manteniendo la relación líquido/sólido de 0,42. Las lechadas se mezclaron a mano durante 3 minutos en un vial. El ensayo se efectuó a $25^{\circ} \mathrm{C}$ con una duración de 12 días.

Se realizó la extracción de la fase líquida de las probetas de lechadas de $5 \times 5 \times 5 \mathrm{~cm}$ curadas a $22 \pm 2{ }^{\circ} \mathrm{C}$ y $95 \%$ de $\mathrm{HR}$, durante 3, 6, 24 h y 7 días. La extracción se realizó mediante un equipo no comercializado diseñado por el investigador Diamond y fabricado en la Universidad de Aston, Birmingham (17). Este equipo está fabricado de un acero que es una aleación especial (SAE-4340) capaz de resistir presiones mecánicas de hasta $550 \mathrm{MPa}$. De la fase líquida extraída se determinó el contenido de $\mathrm{Si}$ mediante colorimetría en un 662 Photometer, el Ca se analizó por cromatografía iónica en un equipo DIONEX HPLC System. Por otra parte la concentración de $\mathrm{Na}, \mathrm{Mg}$ y Al se midió mediante espectrometría de emisión óptica por plasma acoplado inducido (ICP-OES) utilizando el equipo de Varian Mod 725-ES.

Mediante un tratamiento con acetona/etanol se detuvo el proceso de hidratación en la fase sólida resultante. El polvo obtenido se analizó por difracción de rayos $X$ (DRX) en un equipo D8 Advanced de Bruker AXS, en el intervalo $2 \theta$ de $5^{\circ}$ a $60^{\circ}$. Asimismo, se analizó por espectrometría infrarroja por transformada de Fourier (FTIR) utilizando un equipo de Thermo Scientific modelo NICOLET 6700 de en el intervalo de $4000-400 \mathrm{~cm}^{-1}$ utilizando el método del comprimido en $\mathrm{KBr}$. Así como por resonancia magnética nuclear (RMN) de ${ }^{29} \mathrm{Si}$, ${ }^{27} \mathrm{Al}$ en un espectrómetro modelo BRUKER MSL 400.

Por otra parte se realizó un análisis microestructural por microscopía electrónica de barrido y microanálisis de rayos X (SEM/BSE/EDX), en un microscopio JEOL 5400, en las probetas que fueron ensayadas previamente mecánicamente a 28 días de curado.

\subsubsection{Ensayos mecánicos}

Se prepararon lechadas de las mezclas descritas en la Tabla 3. Para cada lechada se prepararon probetas prismáticas de $4 \times 4 \times 16 \mathrm{~cm}$, las cuales fueron curadas inmediatamente después de su preparación a $22 \pm 2{ }^{\circ} \mathrm{C}$ durante 2 y 28 días. En todos los casos la humedad relativa (HR) durante el curado fue superior al 95\%. Los

\subsection{Tests conducted}

\subsubsection{Hydration}

The heat flow rate and total heat released during cement hydration were determined by isothermal conduction calorimetry with a Thermometric TAM Air conduction calorimeter. Five grams of each cement were weighed and mixed with decarbonated water and/or activating solution, maintaining the liquid/solid ratio at 0.42 . The slurries were hand-mixed for 3 minutes in a vial. The 12day test was conducted at $25^{\circ} \mathrm{C}$.

The liquid phase was extracted from $5 \times 5 \times 5-\mathrm{cm}$ slurry specimens after curing at $22 \pm 2{ }^{\circ} \mathrm{C}$ and $95 \% \mathrm{RH}$ for 3,6 and 24 hours and 7 days. The liquid was extracted with non-commercial equipment designed by Diamond and manufactured at Aston University, Birmingham (17). The steel used was a special alloy (SAE - 4340) able to withstand mechanical pressures of up to $550 \mathrm{MPa}$. The $\mathrm{Si}$ content of the extract was found by calorimetry in a 662 photometer; ion chromatography (DIONEX HPLC System) was used to analyze Ca content. $\mathrm{Na}, \mathrm{Mg}$ and $\mathrm{Al}$ concentration values, in turn, were measured with inductively coupled plasma optical emission spectrometry (ICP - OES) on a Varian 725-ES spectrometer.

Hydration in the resulting solid phase was detained with acetone/ethanol. The powder obtained was analysed with X-ray diffraction (XRD) techniques on a Bruker AXS $D 8$ Advanced diffractometer, at a $2 \theta$ angle range of $5^{\circ}$ to 60․ $\mathrm{KBr}$ pellets were prepared for Fourier transform infrared spectrometry (FTIR) and analyzed over a wave number range of $4000-400 \mathrm{~cm}^{-1}$ on a Thermo Scientific NICOLET 6700 spectrometer. Samples were likewise studied with ${ }^{29} \mathrm{Si}$ and ${ }^{27} \mathrm{Al}$ nuclear magnetic resonance (NMR) techniques on a BRUKER MSL 400 spectrometer.

Scanning electron microscopy and X-ray microanalysis (SEM/BSE/EDX) were conducted on a JEOL 5400 microscope to analyse the microstructure of the 28-day specimens after they were tested for mechanical strength.

\subsubsection{Mechanical tests}

Slurries were prepared with the blends described in Table 3. Prismatic specimens measuring $4 \times 4 \times 16 \mathrm{~cm}$ were prepared for each slurry and cured at $22 \pm 2{ }^{\circ} \mathrm{C}$ for 2 and 28 days. In all cases the slurries were cured at over $95 \%$ relative humidity $(\mathrm{RH})$. The compressive and bending strength values were taken as the average of three and 
valores de resistencia a flexión y a compresión fueron el promedio de tres y seis lecturas, respectivamente, y se obtuvieron empleando una prensa IBERTEXT MOD Autotest 200-10-W, de acuerdo a la norma UNE EN196-1 (18).

Se determinó el módulo elástico en compresión sobre probetas de $4 \times 4 \times 16 \mathrm{~cm}$ a 28 días de curado para los cementos activados, así como para la lechada de cemento $\mathrm{H}$. El ensayo se realizó en una máquina INSTRON 5582.

\section{RESULTADOS}

\subsection{Estudio de la hidratación}

\subsubsection{Calorimetría de conducción}

Las curvas de velocidad de evolución de calor asociadas a la masiva precipitación de productos de reacción de las diferentes lechadas se muestran en la Figura 1. De estas gráficas se recopilaron los datos mostrados en la Tabla 4: $t_{\text {inicial }}$ de hidratación se consideró como el punto en el cual la velocidad de liberación de calor está en el valle de la curva, el $t_{\text {max }}$ es el tiempo en el cual se encontró la velocidad máxima de liberación de calor, $t_{\text {final }}$ es el tiempo en el cual la velocidad de calor desprendido no six readings obtained with an IBERTEXT MOD Autotest 200-10-W testing frame, pursuant to Spanish and European standard UNE EN196-1 (18).

The compression elastic modulus was found for activated cement and class $\mathrm{H}$ cement slurry on 28-day, 4 x 4 x 16$\mathrm{cm}$ specimens. This test was conducted with an INSTRON 5582 apparatus.

\section{RESULTS}

\subsection{Hydration}

\subsubsection{Conduction calorimetry}

The heat flow curves associated with the mass precipitation of reaction products in the various slurries are shown in Figure 1. The data given in Table 4 were compiled from these graphs. Initial hydration time, $t_{\text {initial }}$ was regarded to be the heat release nadir preceding the curve, $t_{\max }$ the heat release peak time, $t_{\text {final }}$ the time after which the heat released did not change significantly, and $t_{\text {total }}$ the time lapsing from $t_{\text {initial }}$ to $t_{\text {final. }}$. The peak heat release rate was represented as $V_{\text {max }}$.

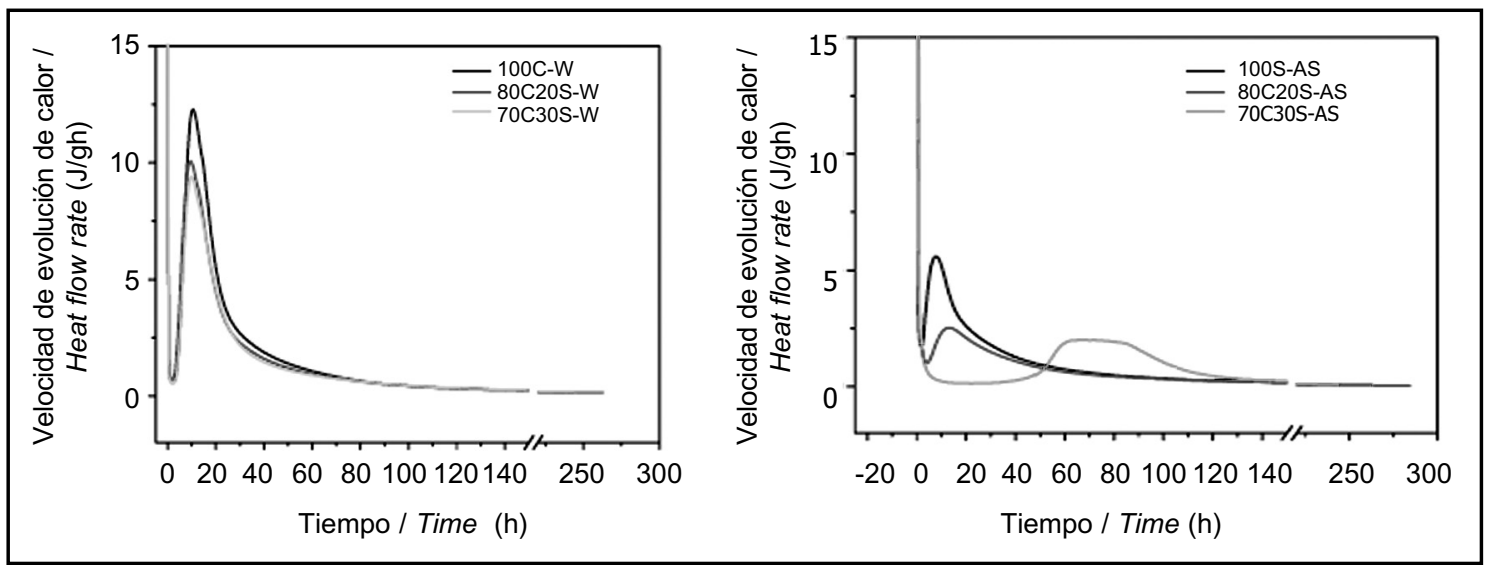

Figura 1. Velocidad de evolución de calor de (a) lechadas mezcladas con agua destilada descarbonatada, (b) lechadas mezcladas con $\mathrm{Na}_{2} \mathrm{SiO}_{3} \cdot 9 \mathrm{H}_{2} \mathrm{O}\left(3,5 \% \mathrm{Na}_{2} \mathrm{O}\right.$ con respecto a la masa de escoria).

Figure 1. Heat flow rate in (a) slurries mixed with distilled decarbonated water and (b) slurries mixed with $\mathrm{Na}_{2} \mathrm{SiO}_{3} \cdot 9 \mathrm{H}_{2} \mathrm{O}$ (3.5\% $\mathrm{Na}_{2} \mathrm{O}$ by slag mass).

Tabla 4 / Table 4

Datos calorimétricos.

Calorimetric data.

\begin{tabular}{|c|c|c|c|c|c|c|c|}
\hline Lechada / S/urry & $\mathbf{t}_{\text {inicial }} / \boldsymbol{t}_{\text {initial }}[\mathrm{h}]$ & $\mathbf{t}_{\text {max }} /[\mathbf{h}]$ & $\mathbf{t}_{\text {final }}[\mathrm{h}]$ & $\mathbf{t}_{\text {tota }}[\mathbf{h}]$ & $\mathbf{V}_{\text {max }}[\mathrm{J} / \mathbf{g h r}]$ & $\mathbf{Q}_{\text {pico }} / \mathbf{Q}_{\text {peak }}[\mathrm{J} / \mathbf{g}]$ & $\mathbf{Q}_{\text {total }} \mathbf{Q}[\mathrm{J} / \mathbf{g}]$ \\
\hline $\mathbf{1 0 0 C - W}$ & 2.129 & 12.282 & 88.950 & 86.820 & 10.531 & 247.963 & 249.145 \\
\hline $\mathbf{8 0 C 2 0 S - W}$ & 1.826 & 9.549 & 91.297 & 89.471 & 10.061 & 216.695 & 217.812 \\
\hline $\mathbf{7 0 C 3 0 S - W}$ & 2.012 & 9.906 & 96.808 & 94.796 & 9.389 & 204.535 & 205.516 \\
\hline $\mathbf{8 0 C 2 0 S - A S}$ & 1.936 & 7.794 & 113.801 & 111.865 & 5.593 & 152.788 & 155.961 \\
\hline 70C30S-AS & 4.305 & 13.153 & 177.638 & 173.334 & 2.528 & 114.241 & 122.533 \\
\hline 100S-AS & 22.339 & 71.487 & 221.690 & 199.350 & 2.003 & 124.538 & 136.445 \\
\hline
\end{tabular}


cambió significativamente, $t_{\text {total }}$ es el tiempo considerado desde el valle de la curva ( $\left.t_{\text {inicial }}\right)$ hasta el tiempo en el cual no hubo variación de la velocidad de liberación de calor $\left(t_{\text {final }}\right)$. $V_{\text {max }}$ es la máxima velocidad de liberación de calor. $Q_{\text {pico }}$ es el calor de hidratación calculado como el área bajo el pico de la curva y $Q_{t o t a l}$ es el calor total desarrollado durante la hidratación.

El pico correspondiente a la etapa de pre-inducción no se observa debido a que el mezclado inicial se hizo manualmente fuera del calorímetro.

En el caso de las lechadas preparadas con agua descarbonatada (Figura 1a), el tiempo al cual se inicia la señal de precipitación es muy semejante entre sí, siendo más corto el de la lechada 80C20S. La velocidad máxima de liberación de calor disminuye a medida que aumenta el contenido de escoria. El tiempo de inicio y duración del pico asociado a la masiva precipitación de productos de reacción se incrementa con el contenido de escoria.

Para las lechadas amasadas con la disolución alcalina (Figura 1b), su periodo de inducción se incrementa. El valor máximo de velocidad de evolución de calor es de casi la mitad para $80 \mathrm{C} 20 \mathrm{~S}$ y un $73 \%$ menor para $70 \mathrm{C} 30 \mathrm{~S}$ con respecto al obtenido en $100 \mathrm{C}-\mathrm{W}$. La lechada $100 \mathrm{~S}$ muestra el mayor periodo de inducción, con un máximo en la velocidad de evolución de calor a $70 \mathrm{~h}$ después de iniciado el ensayo, presentando una meseta que indica un largo periodo de precipitación de los productos de hidratación. El largo periodo de inducción observado en la muestra 100S, así como la forma de la curva calorimétrica son característicos de sistemas de escoria activada con silicato sódico $(12,19,20)$.

El calor del pico se obtuvo integrando la curva de velocidad de hidratación, el final de la curva se consideró como el $5 \%$ de la altura del pico máximo. Se observa que las lechadas amasadas con disolución alcalina desarrollan casi la mitad del calor que las lechadas amasadas con agua descarbonatada (Tabla 4).

\subsubsection{Extracción de la fase acuosa}

\subsubsection{Análisis de la fase acuosa}

Los resultados del análisis químico de las fases acuosas extraídas a 3, 6, 24 h y 7 días de curado se muestran en la Tabla 5.

Para la lechada de $100 \mathrm{C}-\mathrm{W}$, a $3 \mathrm{~h}$ de hidratación, la fase acuosa es en $\mathrm{Ca}^{2+}(82,71 \mathrm{mmol} / \mathrm{l})$ y $\mathrm{Na}^{+}(79,39 \mathrm{mmol} / \mathrm{l})$ y la concentración silicio es de 0,04 mmol/l. En las horas sucesivas va disminuyendo el contenido en calcio
$Q_{\text {peak, }}$ the heat of hydration, was calculated as the area underneath the peak of the curve and $Q_{\text {total }}$ defined to be the total heat released during hydration.

The pre-induction stage peak was not visible because the slurries were mixed manually prior to placement on the calorimeter.

The initial precipitation signal appeared at very similar times in all the slurries prepared with decarbonated water (see Figure 1a), but sooner in slurry 80C20S. The maximum heat release rate declined with increasing proportions of slag, while the initial time and peak duration associated with the mass precipitation of reaction products rose with the slag content.

The induction period, in turn, was longer when the slurries were mixed with the alkaline solution (Figure 1b). The highest heat flow rate for $80 \mathrm{C} 205$ was about half the value recorded for $100 \mathrm{C}-W$, while the rate was $73 \%$ lower for $70 C 305$ than for pure cement. Slurry 1005 had a very long induction period, reaching the maximum heat flow rate 70 hours into the test, followed by a plateau indicative of a lengthy precipitation period for hydration products. The long induction period observed in sample 1005 and the shape of the calorimetric curve are characteristic of sodium silicate-activated slag systems $(12,19,20)$.

Peak heat was calculated by integrating the hydration rate curve, which was defined to end at a value equal to $5 \%$ of the highest value reached. The amount of heat released by the slurries prepared with the alkaline solution was only slightly over half the amount released by the slurries mixed with decarbonated water (see Table 4).

\subsubsection{Extraction of the aqueous phase}

\subsubsection{Analysis of the aqueous phase}

The chemical analysis of the aqueous phases extracted at 3, 6 and 24 hours and 7 days yielded the results given in Table 5.

After 3 hours of hydration, the aqueous phase in slurry 100C-W contained $82.71 \mathrm{mmol} / \mathrm{l} \mathrm{Ca}^{2+}$ and $79.39 \mathrm{mmol} / \mathrm{l}$ $\mathrm{Na}^{+}$, while silicon concentration was $0.04 \mathrm{mmol} / \mathrm{l}$. Thereafter, the calcium content declined (5.24 $\mathrm{mmol} / \mathrm{l})$, 
$(5,24 \mathrm{mmol} / \mathrm{l})$ e incrementando su contenido en sodio (135 mmol/l) y silicio $(2,65 \mathrm{mmol} / \mathrm{l})$. Las concentraciones de aluminio y magnesio se mantuvieron en un intervalo muy estrecho entre $0,04-0,36 \mathrm{mmol} / \mathrm{l}$ y $0,01-0,24 \mathrm{mmol} / \mathrm{l}$, respectivamente. while the sodium (135 $\mathrm{mmol} / \mathrm{l})$ and silicon $(2.65 \mathrm{mmol} / \mathrm{l})$ concentrations grew. The aluminium and magnesium contents ranged very narrowly, from 0.04 to $0.36 \mathrm{mmol} / \mathrm{l}$ and 0.01 to $0.24 \mathrm{mmol} / \mathrm{l}$, respectively.

Tabla 5 / Table 5

Análisis químico de la fase acuosa extraída. Chemical analysis of the aqueous phase extracted.

\begin{tabular}{|c|c|c|c|c|c|c|c|}
\hline & Tiempo / Time [h] & $\mathrm{Na}[\mathrm{mmol} / \mathrm{l}]$ & $\mathrm{Ca}[\mathrm{mmol} / \mathrm{l}]$ & $\mathrm{Si}[\mathrm{mmol} / \mathrm{l}]$ & $\mathrm{Mg}[\mathrm{mmol} / \mathrm{l}]$ & Al [mmol/l] & $\mathrm{pH}$ \\
\hline \multirow{4}{*}{$100 C-W$} & 3 & 79.39 & 82.71 & 0.04 & 0.01 & 0.04 & 12.86 \\
\hline & 6 & 90.26 & 25.01 & 0.03 & 0.24 & 0.01 & 12.85 \\
\hline & 24 & 102.22 & 13.10 & 0.07 & 0.11 & 0.14 & 13.36 \\
\hline & 168 & 135.93 & 5.24 & 2.65 & 0.08 & 0.36 & 13.50 \\
\hline \multirow{4}{*}{$80 \mathrm{C20S}-\mathrm{AS}$} & 3 & 887.38 & 39.55 & 0.33 & 0.04 & 0.05 & 13.00 \\
\hline & 6 & 893.91 & 21.64 & 0.09 & 0.03 & 0.05 & 12.88 \\
\hline & 24 & 802.56 & 2.50 & 2.82 & 0.04 & 0.14 & 13.54 \\
\hline & 168 & 715.56 & 6.99 & 0.95 & 0.07 & 0.14 & 13.57 \\
\hline \multirow{4}{*}{ 70C30S-AS } & 3 & 1057.03 & 25.39 & 0.08 & 0.10 & 0.04 & 13.54 \\
\hline & 6 & 1035.28 & 11.23 & 0.20 & 0.11 & 0.12 & 13.59 \\
\hline & 24 & 1050.50 & 8.73 & 0.57 & 0.01 & 0.00 & 13.47 \\
\hline & 168 & 815.61 & 23.39 & 0.68 & 0.01 & 0.08 & 13.56 \\
\hline \multirow{4}{*}{ 100S-AS } & 3 & 3558.22 & 18.90 & 7.13 & 7.66 & 32.07 & 13.80 \\
\hline & 6 & 2977.51 & 15.91 & 11.44 & 3.30 & 24.07 & 13.78 \\
\hline & 24 & 2992.74 & 2.56 & 11.99 & 0.45 & 16.63 & 13.81 \\
\hline & 168 & 1565.97 & 1.93 & 14.64 & 0.01 & 2.82 & 13.49 \\
\hline
\end{tabular}

En el caso de la lechada 80C20S-AS, a 3 h de hidratación, la disolución contiene una muy alta concentración de iones sodio debido a la adición del silicato sódico como activador; mientras que la concentración de silicio es de 0,33 mmol/l. La concentración de calcio es un 40\% menor que la esperada proporcionalmente a la obtenida para el cemento a este mismo tiempo. Entre 3 y $24 \mathrm{~h}$ de hidratación las concentraciones de calcio y sodio disminuyen. A 24 h de hidratación, la solución tiene aproximadamente las mismas concentraciones de calcio y silicio ( 2,50 y $2,82 \mathrm{mmol} / \mathrm{l}$, respectivamente). Posteriormente, a 7 días la solución incrementa su contenido en calcio $(6,99 \mathrm{mmol} / \mathrm{l})$ y disminuye su concentración de sodio $(715,5 \mathrm{mmol} / \mathrm{l})$ y de silicio $(0,95 \mathrm{mmol} / \mathrm{l})$. Durante este tiempo las concentraciones de aluminio y magnesio oscilaron entre $0,05-0,14 \mathrm{mmol} / \mathrm{l}$ y $0,03-0,07 \mathrm{mmol} / \mathrm{l}$, respectivamente.

Para la lechada 70C30S-AS, nuevamente la concentración de sodio es muy elevada a $3 \mathrm{~h}$ de curado debido a la adición del silicato sódico, en tanto que la concentración de silicio es de $0,08 \mathrm{mmol} / \mathrm{l}$. En este caso, la concentración de calcio es $56 \%$ menor de la esperada proporcionalmente a la obtenida para el cemento a este mismo tiempo de hidratación. Con 24 h de curado, la
After 3 hours of hydration, the solution from slurry 80C20S-AS exhibited a very high concentration of sodium ions due to the addition of the sodium silicate activator, while silicon concentration was $0.33 \mathrm{mmol} / \mathrm{l}$. Calcium concentration was $40 \%$ lower than would be expected on the grounds of the proportion of slag in the blend and the amount obtained in pure cement at this same age. The calcium and sodium concentrations declined between 3 and 24 hours. After hydration for 24 hours, the calcium and silicon concentrations (2.50 and $2.82 \mathrm{mmol} / \mathrm{l}$, respectively) in the solution were approximately the same. The calcium content rose (6.99 $\mathrm{mmol} / \mathrm{l})$ in the solutions from the 7-day slurries, while the sodium (715.5 $\mathrm{mmol} / \mathrm{l})$ and silicon (0.95 mmol/l) concentrations declined. In this time interval, the aluminium and magnesium concentrations ranged from 0.05 to $0.14 \mathrm{mmol} / \mathrm{l}$ and 0.04 to $0.07 \mathrm{mmol} / \mathrm{l}$, respectively.

The sodium concentration was also high in the aqueous phase in the 3-hour 70C30S-AS slurry due to the addition of sodium silicate, whereas the silicon concentration was $0.08 \mathrm{mmol} / \mathrm{l}$. In this case, calcium concentration was $56 \%$ lower than would be expected on the grounds of the proportion of slag in the blend and the [Ca] in pure cement at this same age. After 24 hours, the liquid phase 
fase acuosa ha disminuido el $65 \%$ del contenido de calcio que se tenía a $3 \mathrm{~h}$, sin embargo a 7 días la concentración de calcio vuelve a incrementarse hasta casi obtener la misma que se tenía a $3 \mathrm{~h}$. Por otra parte, el contenido de silicio se ha incrementado gradualmente hasta llegar a 0,68 mmol/l. La concentración de sodio disminuye progresivamente, siendo a 7 días un $22 \%$ menor de la encontrada a 3 horas. Las concentraciones de aluminio y magnesio han variado entre un $0,04-0,12 \mathrm{mmol} / \mathrm{l}$ y $0,01-0,11 \mathrm{mmol} / \mathrm{l}$, respectivamente.

En la lechada de $100 \mathrm{~S}$, a $3 \mathrm{~h}$ de curado, la disolución tiene un elevado contenido de sodio debido a la adición de silicato sódico, sin embargo la concentración de silicio es de $7,13 \mathrm{mmol} / \mathrm{l}$. En este caso se aprecia un mayor contenido en disolución de aluminio y magnesio. A medida que avanza la hidratación, los contenidos de sodio, aluminio, calcio y magnesio disminuyen y se incrementa la concentración de silicio.

\subsubsection{Análisis de la fase sólida}

\subsection{Difracción de Rayos $X$}

Una vez extraída la fase líquida, la fase sólida se analizó mediante DRX. La identificación de las fases anhidras e hidratadas por DRX de las lechadas curadas a 3, 6, 24h y 7 días se muestra en la Figura 2. Todos los difractogramas presentan un cierto desplazamiento en sus líneas de difracción, así como cierta orientación preferencial.

El cemento anhidro se compone principalmente por $\mathrm{C}_{3} \mathrm{~S}$, $\mathrm{B}_{-} \mathrm{C}_{2} \mathrm{~S}, \mathrm{C}_{4} \mathrm{AF}$ y $\mathrm{CaSO}_{4} \cdot 2 \mathrm{H}_{2} \mathrm{O}$. La identificación del $\mathrm{C}_{3} \mathrm{~A}$ no fue posible debido a su bajo contenido. Como consecuencia del proceso de hidratación se aprecia por una parte, la aparición progresiva de portlandita, así como de etringita, y por otra la consumición de $\mathrm{C}_{3} \mathrm{~S}$ y yeso principalmente. En cuanto a la fase ferrítica $\left(C_{4} A F\right)$ no se aprecia un cambio considerable en la intensidad de sus líneas.

En el caso de 80C20S-AS y 70C30S-AS se observan las fases $\mathrm{C}_{3} \mathrm{~S}, \mathrm{~B}-\mathrm{C}_{2} \mathrm{~S}, \mathrm{C}_{4} \mathrm{AF}$ y $\mathrm{CaSO}_{4} \cdot 2 \mathrm{H}_{2} \mathrm{O}$. A 3 h de curado la cantidad de portlandita que se forma es menor que la esperada proporcionalmente de acuerdo a la obtenida a $3 \mathrm{~h}$ en $100 \mathrm{C}$, y su crecimiento es más lento. En cuanto a la etringita, en $80 \mathrm{C20S}$-AS se aprecia hasta las $24 \mathrm{~h}$ de curado, mientras que en 70C30S-AS a 7 días de curado no es posible identificarla en el difractograma.

Para la muestra 100S-AS, debido a su alto contenido de fase vítrea, únicamente se aprecia un halo amorfo entre $30-32^{\circ}$ de $2 \theta$, indicativo de la presencia de la disolución sólida de melilita y una ligera carbonatación (o meteorización) con formación de calcita a partir de los 7 días de curado. had lost $65 \%$ of the calcium content recorded after three hours, whereas after 7 days the concentration of this ion returned to nearly the 3-hour level. Silicon content, in turn, gradually increased to $0.68 \mathrm{mmol} / \mathrm{l}$. At the end of a steady decline, the 7-day sodium concentration stood at $22 \%$ below the 3-hour value. The aluminium and magnesium concentrations ranged from 0.04 to 0.12 $\mathrm{mmol} / \mathrm{l}$ and 0.01 to $0.11 \mathrm{mmol} / \mathrm{l}$, respectively.

The solution extracted from 3-hour slurry 100 s showed a high sodium content due to the addition of sodium silicate, although the silicon concentration was 7.13 $\mathrm{mmol} / \mathrm{l}$. The aluminium and magnesium concentrations were higher in this case. As hydration progressed, the sodium, aluminium, calcium and magnesium contents declined, while the silicon concentration rose.

\subsubsection{Analysis of the solid phase}

\subsection{X-ray diffraction}

The solid phase remaining after extraction of the liquid phase was analyzed with XRD. The anhydrous and hydrated phases identified with XRD in the 3-, 6- and 24hour and 7-day slurries are shown in Figure 2. All the diffractograms exhibited a certain lag in their diffraction lines as well as a preference for a given orientation.

The anhydrous cement consisted primarily of $C_{3} S, B-C_{2} S$, $\mathrm{C}_{4} \mathrm{AF}$ and $\mathrm{CaSO}_{4} \cdot 2 \mathrm{H}_{2} \mathrm{O}$. No $\mathrm{C}_{3} \mathrm{~A}$ could be identified, due to the low content of this compound. Both portlandite and ettringite were observed to gradually appear as a result of the hydration process, while the proportions of other constituents, primarily $C_{3} S$ and gypsum, waned. No significant change was observed in the intensity of the ferrite phase $\left(C_{4} A F\right)$ lines.

The phases visible in 80C20S-AS and 70C30S-AS were $\mathrm{C}_{3} \mathrm{~S}, \mathrm{~B}-\mathrm{C}_{2} \mathrm{~S}, \mathrm{C}_{4} \mathrm{AF}$ and $\mathrm{CaSO}_{4} \cdot 2 \mathrm{H}_{2} \mathrm{O}$. Less portlandite formed after 3 hours than would be expected on the grounds of the proportion of slag in the blend and the amount obtained in 3-hour 100C specimens. Moreover, its concentration grew more slowly than in the pure cement pastes. Ettringite, in turn, was visible up to 24 hours in 80C20S-AS but could not be identified on the 7day XRD patterns for 70C30S-AS.

Due to the high vitreous content in 100S-AS, the sole signal observed, an amorphous halo in the $30^{\circ}-32^{\circ} 2 \theta$ angle range, indicated the presence of a solid melilite solution and slight weathering, with calcite formation after 7 days. 


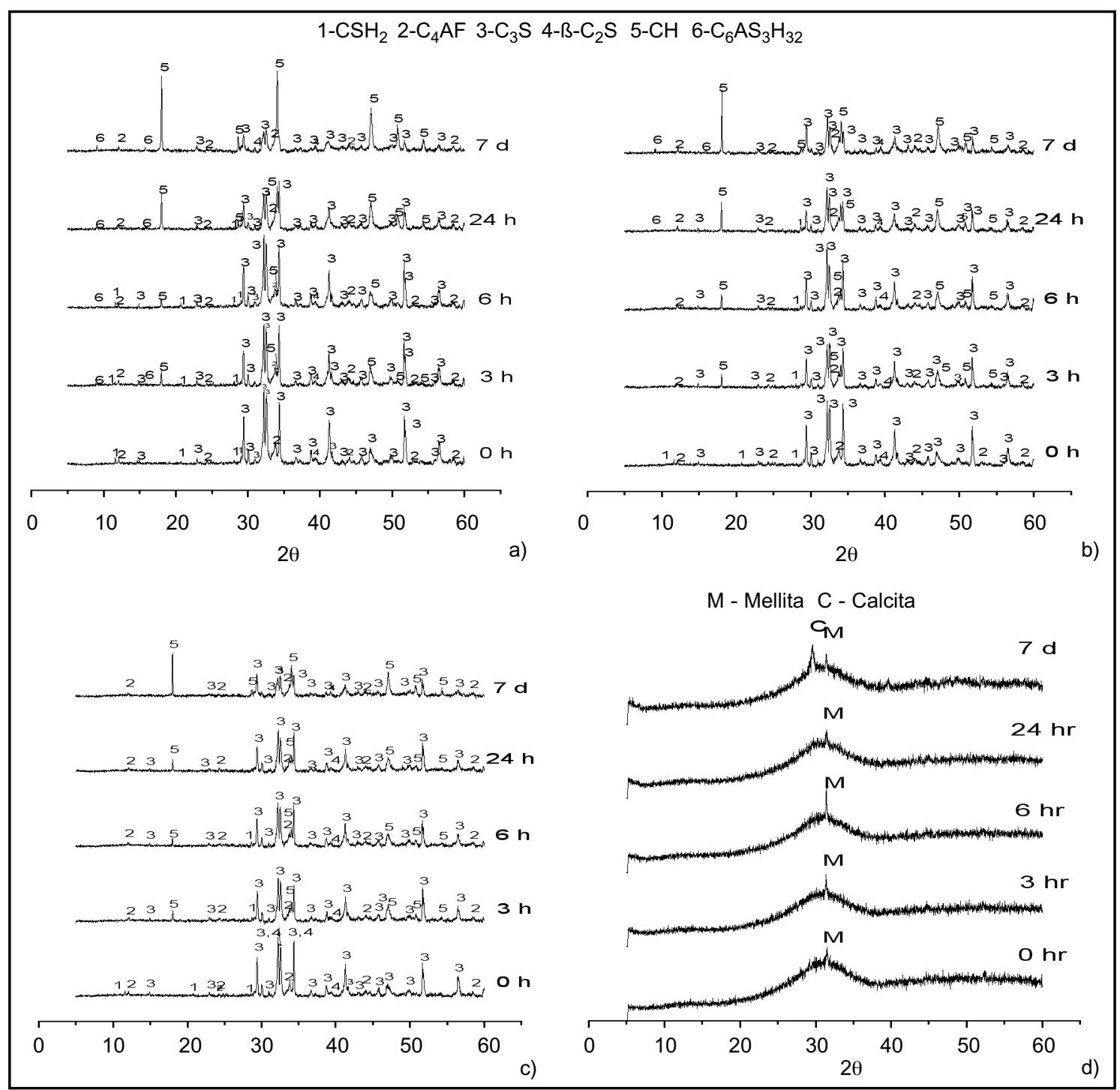

Figura 2. DRX a $0,3,6,24 \mathrm{hr}$ y 7 días de curado a $20^{\circ} \mathrm{C}$ para (a) $100 \mathrm{C}-\mathrm{W}$, (b) $80 \mathrm{C} 20 \mathrm{~S}-\mathrm{AS}$, (c) $70 \mathrm{C} 30 \mathrm{~S}-\mathrm{AS}$ y (d) $100 \mathrm{~S}-\mathrm{AS}$. Figure 2. XRD traces for 0-, 3-, 6- and 24-hour and 7-day pastes cured at $20^{\circ} \mathrm{C}$ : (a) $100 \mathrm{C}-\mathrm{W}$, (b) $80 \mathrm{C} 20 \mathrm{~S}-\mathrm{AS}$, (c) 70C30S-AS and (d) 100S-AS.

3.1.2.2.2. Espectroscopía infrarroja por transformada de Fourier (FTIR)

En la Figura $3 a$ se observan los espectros obtenidos mediante FTIR de la fase sólida a 3, 6, 24 h y 7 días de curado para $100 \mathrm{C}$. En el cemento anhidro se observan dos bandas a 922 y $886 \mathrm{~cm}^{-1}$ correspondientes a la vibración $v_{3}(\mathrm{Si}-\mathrm{O})$ del $\mathrm{C}_{3} \mathrm{~S}$. A $520 \mathrm{~cm}^{-1}$ se presenta la banda correspondiente a la vibración $v_{1}(\mathrm{Si}-\mathrm{O}-\mathrm{Si})$ del $\mathrm{C}_{3} \mathrm{~S}$. La banda presente a $845 \mathrm{~cm}^{-1}$ se atribuye a la vibración $v_{1}(\mathrm{Si}-\mathrm{O})$ del $\mathrm{B}-\mathrm{C}_{2} \mathrm{~S}(21,22)$. Las bandas encontradas entre 600 y $700 \mathrm{~cm}^{-1}$ corresponden al $\mathrm{AlO}_{4}$ y $\mathrm{FeO}_{4}$ del $\mathrm{C}_{4} \mathrm{AF}$. Entre 1.100 y 1.140 se presentan tres bandas de vibración asociadas a $v_{3}$ del $\mathrm{SO}_{4}{ }^{2-}$ de una mezcla de yeso y singenita. Durante el desarrollo de la hidratación se advierte que la banda localizada a $920 \mathrm{~cm}^{-1}$ se desplaza hacia números de onda superiores $\left(970 \mathrm{~cm}^{-1}\right)$ y se

\subsection{Fourier transform infrared spectroscopy (FTIR)}

Figure 3a shows the FTIR spectra obtained for the solid phase in 3-, 6- and 24-hour and 7-day 100C samples. The two bands at 922 and $886 \mathrm{~cm}^{-1}$ observed in the anhydrous cement were attributed to the $v_{3}$ (Si-O) vibrations in the $C_{3} S$. The band appearing at $520 \mathrm{~cm}^{-1}$ was assigned to the $v_{1}$ (Si-O-Si) vibrations in that same compound. The band at $845 \mathrm{~cm}^{-1}$ was attributed to $v_{1}$ (Si-O) vibrations in $\mathrm{B}-\mathrm{C}_{2} S(21,22)$. The bands between 600 and $700 \mathrm{~cm}^{-1}$ were assigned to the $\mathrm{AlO}_{4}$ and $\mathrm{FeO}_{4}$ in $C_{4} A F$. Three vibrations bands associated with $v_{3}$ vibrations generated by the $\mathrm{SO}_{4}{ }^{2-}$ in a mix of gypsum and syngenite appeared between 1100 and $1140 \mathrm{~cm}^{-1}$. During hydration, the band at $920 \mathrm{~cm}^{-1}$ shifted to higher wave numbers $\left(970 \mathrm{~cm}^{-1}\right)$ and grew more intense due to 


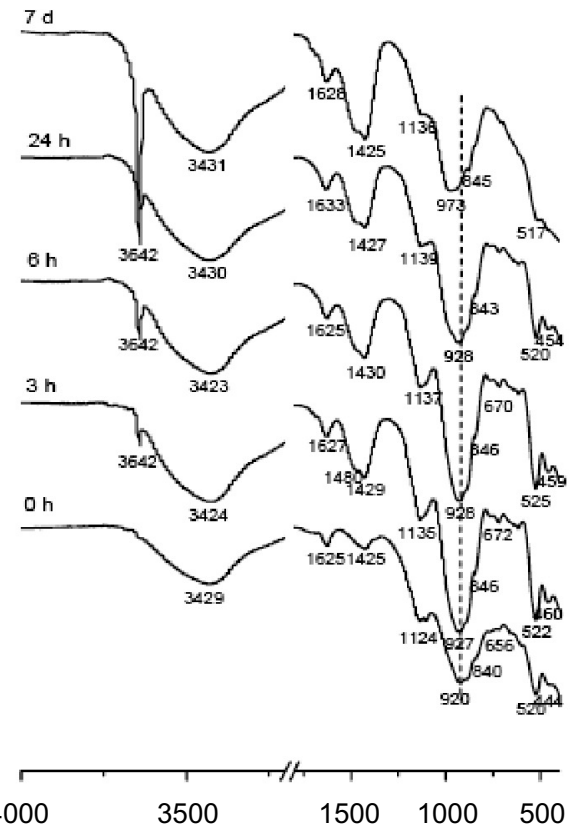

Número de onda / Wave number $\left(\mathrm{cm}^{-1}\right)$

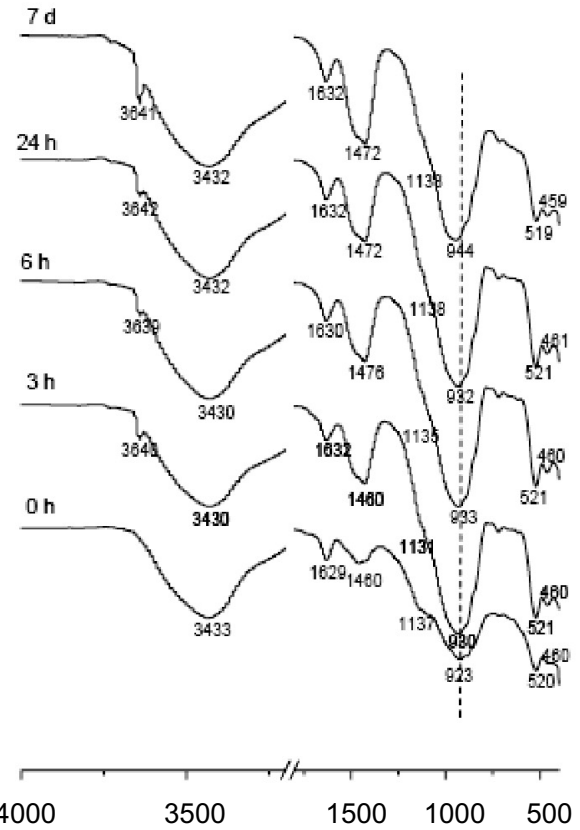

Número de onda / Wave number $\left(\mathrm{cm}^{-1}\right)$

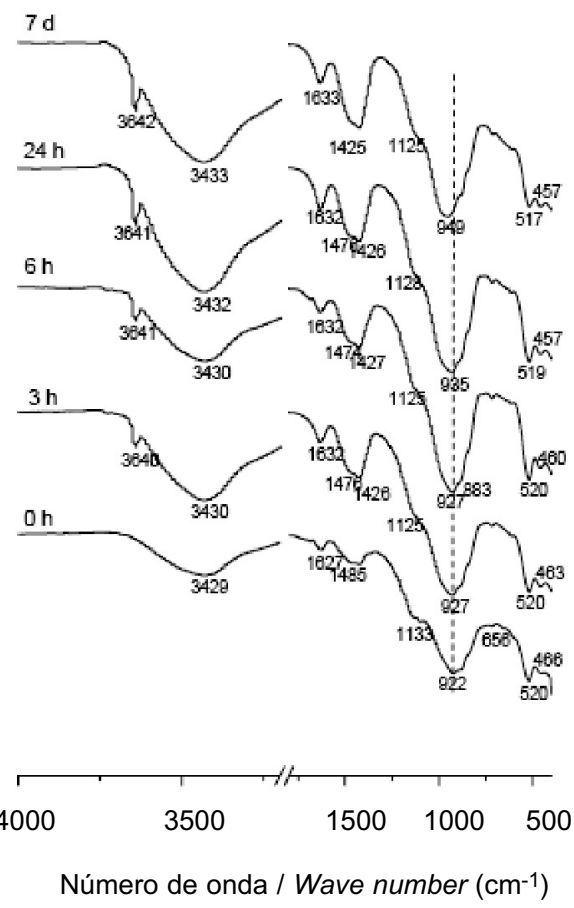

a) b)

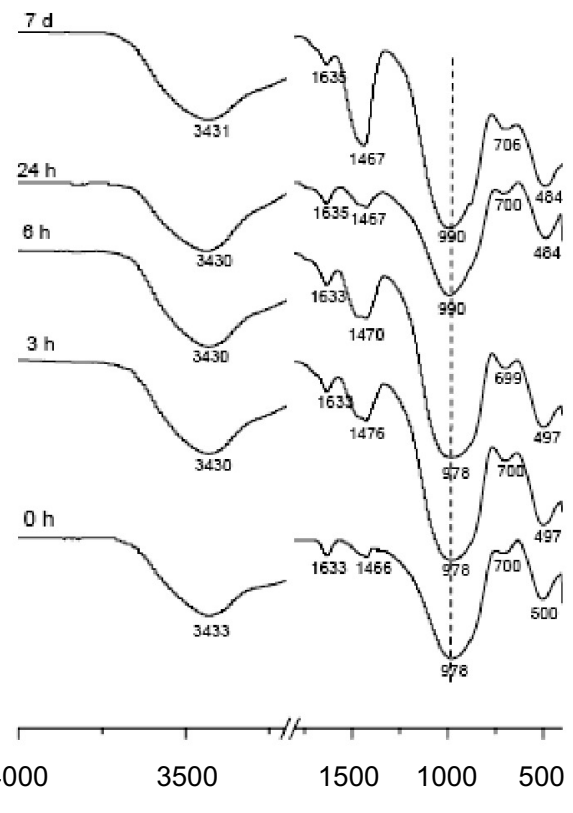

Número de onda / Wave number $\left(\mathrm{cm}^{-1}\right)$

Figura 3. Espectros de FTIR a 0, 3, 6, 24hr y 7 días de curado a $20^{\circ} \mathrm{C}$ para (a) $100 \mathrm{C}-\mathrm{W}$, (b) $80 \mathrm{C} 20 \mathrm{~S}-\mathrm{AS}$, (c) $70 \mathrm{C} 30 \mathrm{~S}-\mathrm{AS}$ y (d) $100 \mathrm{~S}-\mathrm{AS}$.

Figure 3. FTIR spectra for 0-, 3-, 6- and 24-hour and 7-day pastes cured at $20^{\circ} \mathrm{C}$ : (a) 100C-W, (b) 80C20S-AS, (c) 70C30S-AS and (d) 100S-AS.

hace más intensa debido a la formación del gel C-S-H. Asimismo, se aprecia la formación de una banda estrecha y aguda a $3.640 \mathrm{~cm}^{-1}$ correspondiente a la vibración $v_{1}$ del $\mathrm{O}-\mathrm{H}$ de la portlandita. Por otra parte, la banda the formation of $\mathrm{CSH}$ gel. At the same time, a narrow band appeared at $3640 \mathrm{~cm}^{-1}$, attributed to the $v_{1}$ vibrations generated by the $\mathrm{O}-\mathrm{H}$ in portlandite. The wide band at $1430 \mathrm{~cm}^{-1}$, in turn, denoted sample weathering 
ancha a $1.430 \mathrm{~cm}^{-1}$ indica la meteorización de la muestra, también observada por DRX, con formación de calcita. Las bandas que se encontraban entre 1.100 y 1.140 $\mathrm{cm}^{-1}$ se transforman en una sola banda a $1.130 \mathrm{~cm}^{-1}$ características de la presencia de etringita.

En el caso de 80C20S-AS y 70C30S-AS (Figura 3b y 3c respectivamente), las bandas que se observan son prácticamente las mismas, sin embargo en este caso la banda de los silicatos ( $\mathrm{Si}-\mathrm{O}$ ) es más ancha. La banda de los sulfatos es más difusa, así como las bandas entre 600 y $700 \mathrm{~cm}^{-1}$. Durante la hidratación, el desplazamiento de la banda de los silicatos es menos pronunciado $\left(949 \mathrm{~cm}^{-1}\right.$ para $80 C 20 \mathrm{~S}$ y $940 \mathrm{~cm}^{-1}$ para $70 \mathrm{C} 30 \mathrm{~S}$ ). Se aprecia que la cantidad de portlandita que se forma es mucho menor y su crecimiento más lento. Estas muestras también se observan signos de meteorización.

En cuanto a la escoria anhidra (Figura 3d) se observa una banda ancha e intensa hacia $970 \mathrm{~cm}^{-1}$ y otra menor hacia $500 \mathrm{~cm}^{-1}$ asociadas a las vibraciones $v_{3}$ y $v_{1}$ del enlace Si-O, respectivamente. Entre 650 y $800 \mathrm{~cm}^{-1}$ se localizan las bandas de tensión correspondientes a los enlaces $\mathrm{Al}-\mathrm{O}$ de los grupos $\mathrm{AlO}_{4}$ de la escoria. La banda de $1.440 \mathrm{~cm}^{-1}$ indica una parcial carbonatación de la escoria (meteorización). A medida que la hidratación avanza la banda correspondiente a los silicatos se hace más estrecha y tiene un ligero desplazamiento hacia 990 $\mathrm{cm}^{-1}$ y la banda a $500 \mathrm{~cm}^{-1}$ se desplaza ligeramente hacia $480 \mathrm{~cm}^{-1}$. También se detectan entre $1.420 \mathrm{y}$ $1.480 \mathrm{~cm}^{-1}$ las bandas de vibración asociadas a calcita y aragonito, confirmando la parcial meteorización de la muestra $(21,22)$.

\subsection{Resonancia magnética nuclear (RMN)}

Las Figuras 4-11 muestran los espectros ${ }^{29} \mathrm{Si}$ y $27 \mathrm{Al}$ RMN MAS de los cementos anhidros así como de las pastas hidratadas 100C-W, 80C20S-AS, 70C30S-AS y 100S-AS, respectivamente. Asimismo, la Tabla 6 muestra los datos obtenidos de la deconvolución de dichos espectros.

El espectro de ${ }^{29} \mathrm{Si}$ RMN MAS del cemento anhidro $100 \mathrm{C}$ muestra 3 señales (-69,3 ppm, $-71,65$ ppm y $-74,27$ ppm) asociadas a las unidades de $\mathrm{Si} \mathrm{Q}^{0}$ del $\mathrm{C}_{3} \mathrm{~S}$ y $\mathrm{C}_{2} \mathrm{~S}$. Estas mismas señales se observan en los espectros de las pastas hidratadas $100 \mathrm{C}-\mathrm{W}$ a 3 horas y 6 horas de hidratación. Sin embargo, a 24 horas y 7 días de hidratación se detectan adicionalmente 2 señales hacia $-79,0$ ppm y $-85,0$ ppm asociadas a las unidades de Si $Q^{1}$ y $Q^{2}$ (OAl) del gel C-S-H $(23,24)$. Los espectros de ${ }^{29} \mathrm{Si}$ RMN MAS de los cementos anhidros $80 C 205$ y $70 C 30 S$ muestran también 3 señales entre -69 ppm y -75 ppm asignadas a unidades de $\mathrm{Si} \mathrm{Q}^{0}$ de las fases anhidras $\mathrm{C}_{3} \mathrm{~S}$ y $\mathrm{C}_{2} \mathrm{~S}$. La señal que aparece entorno a -75 ppm corresponde a la superposición de dos señales, las asociadas al $\mathrm{C}_{3} \mathrm{~S}$ y a and calcite formation, confirming the $X R D$ results. The bands between 1100 and $1140 \mathrm{~cm}^{-1}$ merged into a single band at $1130 \mathrm{~cm}^{-1}$, characteristic of the presence of ettringite.

Practically the same bands were found for slurries 80C20S-AS and 70C30S-AS (Figures $3 b$ and 3c, respectively), although here the silicate band (Si-O) was much wider. The sulphate band was more diffuse, as were the bands between 600 and $700 \mathrm{~cm}^{-1}$. The shift in the silicate band during hydration was less pronounced (949 $\mathrm{cm}^{-1}$ for $80 \mathrm{C} 20 \mathrm{~S}$ and $940 \mathrm{~cm}^{-1}$ for 70C30S). Much less portlandite was observed to form, and its concentration grew more slowly. These samples also showed signs of weathering.

A wide, intense band was visible at around $970 \mathrm{~cm}^{-1}$ in the anhydrous slag (Figure 3d), along with another smaller band at around $500 \mathrm{~cm}^{-1}$, respectively associated with the $v_{3}$ and $v_{1}$ vibrations generated by the Si-O bond. The stretching bands assigned to the Al-O bonds in the $\mathrm{AlO}_{4}$ groups present in the slag were located between 650 and $800 \mathrm{~cm}^{-1}$. The band at $1440 \mathrm{~cm}^{-1}$ was indicative of partial slag carbonation (weathering). As hydration advanced, the silicate band narrowed and shifted slightly to $990 \mathrm{~cm}^{-1}$, while the band at $500 \mathrm{~cm}^{-1}$ moved slightly to $480 \mathrm{~cm}^{-1}$. Other vibration bands detected between 1420 and $1480 \mathrm{~cm}^{-1}$ and attributed to calcite and aragonite confirmed the partial weathering of the sample $(21,22)$.

\subsection{Nuclear magnetic resonance (NMR)}

The ${ }^{29} \mathrm{Si}$ and ${ }^{27} \mathrm{Al}$ MAS NMR spectra for the anhydrous cement as well as for hydrated pastes $100 \mathrm{C}-W, 80 \mathrm{C} 20 \mathrm{~S}-$ AS, 70C30S-AS and 100S-AS are reproduced in Figures 4-11, respectively. The deconvolution data for these spectra are given in Table 6.

The three signals (-69.3, -71.65 and -74.27 ppm) on the MAS NMR spectrum for $100 C$ anhydrous cement were associated with the Si $Q^{0}$ species in $C_{3} S$ and $C_{2} S$. These same signals were observed in the 3- and 6-hour hydrated $100 \mathrm{C}-\mathrm{W}$ pastes. In the 24-hour and 7-day materials, however, two additional signals were detected, at around 79.0 and 85.0 ppm, associated with the Si $Q^{1}$ and $Q^{2}(O A I)$ species in the $C S H$ gel $(23,24)$. Anhydrous cements 80C20S-AS and 70C30S-AS also had three signals on their ${ }^{29} \mathrm{Si}$ MAS NMR spectra between 69 and -75 ppm, assigned to the Si $Q^{0}$ species in anhydrous phases $C_{3} S$ and $C_{2} S$. The signal appearing at around -75 ppm was actually two concurrent signals, associated with $C_{3} S$ and anhydrous slag. Nonetheless, 
Tabla 6 / Table 6

Deconvolución de los espectros de 29Si RMN MAS de las mezclas anhidras e hidratadas 100C-W, 80C20S-AS, 70C30S-AS y 100S-AS. Deconvoluted spectra 29Si MNR MAS of anhydra and hydrated samples 100C-W, 80C20S-AS, 70C30S-AS and 100S-AS.

\begin{tabular}{|c|c|c|c|c|c|c|c|c|c|}
\hline $\begin{array}{c}\text { Muestra I } \\
\text { Sample }\end{array}$ & $\begin{array}{c}\text { Tiempo de curado } \\
\text { / Curing time }\end{array}$ & \multicolumn{3}{|c|}{$\mathbf{Q}^{\circ}$} & \multirow{2}{*}{$\frac{\text { Q1 (0AI) }}{-}$} & \multirow{2}{*}{$\frac{\text { Q2 (1Al) }}{-}$} & \multirow{2}{*}{$\frac{\text { Q2 (0AI) }}{-}$} & \multirow{2}{*}{$\frac{\text { Q3 (1Al) }}{-}$} & \multirow{2}{*}{$\frac{\text { Q3 (OAI) }}{-}$} \\
\hline \multirow{10}{*}{$100 \mathrm{C}-\mathrm{W}$} & \multirow{2}{*}{$\begin{array}{l}\text { Anhidro / } \\
\text { Anhydrous }\end{array}$} & $-69.3 p p m$ & $-71.6 \mathrm{ppm}$ & $-74.3 p p m$ & & & & & \\
\hline & & $15.79 \%$ & $52.63 \%$ & $31.58 \%$ & - & - & - & - & - \\
\hline & \multirow{2}{*}{$3 \mathrm{~h}$} & $-69.3 \mathrm{ppm}$ & $-71.5 \mathrm{ppm}$ & $-74.2 \mathrm{ppm}$ & - & - & - & - & - \\
\hline & & $17.58 \%$ & $53.91 \%$ & $28.51 \%$ & - & - & - & - & - \\
\hline & \multirow{2}{*}{$6 \mathrm{~h}$} & $-68.9 \mathrm{ppm}$ & $-71.2 \mathrm{ppm}$ & $-73.7 \mathrm{ppm}$ & - & - & - & - & - \\
\hline & & $14.56 \%$ & $52.16 \%$ & $33.28 \%$ & - & - & - & - & - \\
\hline & \multirow{2}{*}{$24 \mathrm{~h}$} & $-68.4 \mathrm{ppm}$ & $-71.4 \mathrm{ppm}$ & $-74.3 \mathrm{ppm}$ & $-79.2 \mathrm{ppm}$ & $-84.6 \mathrm{ppm}$ & - & - & - \\
\hline & & $7.13 \%$ & $43.57 \%$ & $18.85 \%$ & $21.40 \%$ & $9.03 \%$ & - & - & - \\
\hline & \multirow{2}{*}{7 días / days } & $-68.8 \mathrm{ppm}$ & $-71.5 \mathrm{ppm}$ & $-74.1 \mathrm{ppm}$ & $-79.1 \mathrm{ppm}$ & $-84.6 \mathrm{ppm}$ & - & - & - \\
\hline & & $5.7 \%$ & $27.57 \%$ & $11.64 \%$ & $34.51 \%$ & $18.49 \%$ & - & - & - \\
\hline \multirow{10}{*}{$80 \mathrm{C} 20 \mathrm{~S}-\mathrm{AS}$} & \multirow{2}{*}{$\begin{array}{l}\text { Anhidro / } \\
\text { Anhydrous }\end{array}$} & $-69.0 \mathrm{ppm}$ & $-71.8 \mathrm{ppm}$ & $-74.5 \mathrm{ppm}$ & - & - & - & - & - \\
\hline & & $16.41 \%$ & $54.54 \%$ & $29.04 \%$ & - & - & - & - & - \\
\hline & \multirow{2}{*}{$3 \mathrm{~h}$} & $-68.8 \mathrm{ppm}$ & $-71.5 \mathrm{ppm}$ & $-74.5 \mathrm{ppm}$ & $-79.2 \mathrm{ppm}$ & $-82.2 \mathrm{ppm}$ & $-85.3 \mathrm{ppm}$ & - & - \\
\hline & & $15.30 \%$ & $43.45 \%$ & $20.42 \%$ & $9.49 \%$ & $6.11 \%$ & $5.22 \%$ & - & - \\
\hline & \multirow{2}{*}{$6 \mathrm{~h}$} & $-68.3 \mathrm{ppm}$ & $-71.2 \mathrm{ppm}$ & $-73.9 \mathrm{ppm}$ & $-78.1 \mathrm{ppm}$ & $-81.0 \mathrm{ppm}$ & $-84.8 \mathrm{ppm}$ & - & - \\
\hline & & $13.40 \%$ & $44.95 \%$ & $22.35 \%$ & $7.70 \%$ & $5.70 \%$ & $5.90 \%$ & - & - \\
\hline & \multirow{2}{*}{$24 \mathrm{~h}$} & $-69.0 \mathrm{ppm}$ & $-71.7 \mathrm{ppm}$ & $-74.9 \mathrm{ppm}$ & $-79.0 \mathrm{ppm}$ & $-82.5 \mathrm{ppm}$ & $-85.7 \mathrm{ppm}$ & - & - \\
\hline & & $12.98 \%$ & $38.00 \%$ & $17.62 \%$ & $14.22 \%$ & $8.80 \%$ & $8.36 \%$ & - & - \\
\hline & \multirow{2}{*}{7 días / days } & $-68.1 \mathrm{ppm}$ & $-71.4 \mathrm{ppm}$ & $-74.6 \mathrm{ppm}$ & $-78.5 \mathrm{ppm}$ & $-81.9 \mathrm{ppm}$ & $-85.0 \mathrm{ppm}$ & - & - \\
\hline & & $6.28 \%$ & $31.56 \%$ & $16.38 \%$ & $20.88 \%$ & $11.60 \%$ & $13.29 \%$ & - & - \\
\hline \multirow{10}{*}{ 70C30S-AS } & \multirow{2}{*}{$\begin{array}{l}\text { Anhidro / } \\
\text { Anhydrous }\end{array}$} & $-69.0 \mathrm{ppm}$ & $-71.3 \mathrm{ppm}$ & $-74.0 \mathrm{ppm}$ & - & - & - & - & - \\
\hline & & $29.29 \%$ & $47.23 \%$ & $28.47 \%$ & - & - & - & - & - \\
\hline & \multirow{2}{*}{$3 \mathrm{~h}$} & $-69.0 \mathrm{ppm}$ & $-71.7 \mathrm{ppm}$ & $-75.0 \mathrm{ppm}$ & $-78.8 \mathrm{ppm}$ & $-82.3 \mathrm{ppm}$ & $-85.8 \mathrm{ppm}$ & - & - \\
\hline & & $7.77 \%$ & $45.98 \%$ & $17.74 \%$ & $12.17 \%$ & $8.78 \%$ & $7.56 \%$ & - & - \\
\hline & \multirow{2}{*}{$6 \mathrm{~h}$} & $-68.5 \mathrm{ppm}$ & $-71.2 \mathrm{ppm}$ & $-74.2 \mathrm{ppm}$ & $-79.0 \mathrm{ppm}$ & $-82.0 \mathrm{ppm}$ & $-85.0 \mathrm{ppm}$ & - & - \\
\hline & & $9.05 \%$ & $40.74 \%$ & $24.31 \%$ & $11.28 \%$ & $5.70 \%$ & $8.90 \%$ & - & - \\
\hline & \multirow{2}{*}{$24 \mathrm{~h}$} & -68.0 & -71.51 & -74.59 & -78.9 & -82.5 & -85.7 & - & - \\
\hline & & $6.94 \%$ & $40.95 \%$ & $19.53 \%$ & $14.27 \%$ & $10.48 \%$ & $7.83 \%$ & - & - \\
\hline & \multirow{2}{*}{7 días / days } & $-69.2 \mathrm{ppm}$ & $-71.6 \mathrm{ppm}$ & $-74.6 \mathrm{ppm}$ & $-78.9 \mathrm{ppm}$ & $-81.5 \mathrm{ppm}$ & $-84.5 \mathrm{ppm}$ & - & - \\
\hline & & $6.17 \%$ & 28.50 & 14.47 & 25.42 & $7.50 \%$ & $17.93 \%$ & - & - \\
\hline & Anhidro / & $-76.0 \mathrm{ppm}$ & - & - & - & - & - & - & - \\
\hline & Anhydrous & $100 \%$ & - & - & - & - & - & - & - \\
\hline & $3 \mathrm{~h}$ & $-76.0 \mathrm{ppm}$ & - & - & - & - & - & - & - \\
\hline & $3 \mathrm{n}$ & $100 \%$ & - & - & - & - & - & - & - \\
\hline 100S-AS & $6 \mathrm{~h}$ & $-76.0 \mathrm{ppm}$ & - & - & - & - & - & - & - \\
\hline & $6 \mathrm{n}$ & $100 \%$ & - & - & - & - & - & - & - \\
\hline & $24 \mathrm{~h}$ & $-76.0 \mathrm{ppm}$ & - & - & - & - & - & - & - \\
\hline & $24 \mathrm{~h}$ & $100 \%$ & - & - & - & - & - & - & - \\
\hline & 7 días / davs & -67.0 & - & $\begin{array}{r}-73.30 \\
\end{array}$ & -77.80 & -81.40 & -85.30 & -92.00 & -99.32 \\
\hline & / aids / adys & $8.02 \%$ & - & $20.30 \%$ & 15.49 & $11.74 \%$ & $23.15 \%$ & $15.14 \%$ & $6.16 \%$ \\
\hline
\end{tabular}

la escoria anhidra. Sin embargo, y a diferencia de lo observado en las pastas hidratadas del cemento 100C, en las pastas 80 C20S-AS y 70C30S-AS se detectan adicionalmente, desde las 3 horas de curado, 3 señales en torno a $-79,0$ ppm; $-82,0$ ppm y $-85,0$ ppm asociadas a unidades de $\mathrm{Si} \mathrm{Q}^{1}, \mathrm{Q}^{2}(1 \mathrm{Al})$ y $\mathrm{Q}^{2}(\mathrm{OAl})$ del gel C-S-H. Finalmente, el espectro de ${ }^{29} \mathrm{Si}$ RMN MAS de la escoria anhidra, así como los de la escoria activada alcalinamente a 3 horas, 6 horas, y 24 días de hidratación muestran una unlike the hydrated $100 \mathrm{C}$ cement pastes, the 80C20S-AS and 70C30S-AS pastes exhibited three additional signals on their 3-hour MAS NMR spectra, at around -79.0 ppm, -82.0 ppm and -85.0 ppm, respectively associated with silicon $Q^{1}, Q^{2}(1 A l)$ and $Q^{2}(O A l)$ species in the CSH gel. Finally, the ${ }^{29} \mathrm{Si}$ MAS NMR spectrum for the anhydrous slag, as well as the 3-, 6- and 24-hour alkali-activated slag, had a signal centred at around -76.00 ppm, attributed to the Si $Q^{0}$ and $Q^{1}$ species in the slag. The 
señal centrada en torno a -76,00 ppm asignada a unidades de $\mathrm{Si} \mathrm{Q}^{0}$ y $\mathrm{Q}^{1}$ de la escoria. El espectro de la pasta de escoria activada alcalinamente a 7 días de hidratación muestra claras diferencias con respecto a los anteriormente descritos. A ambas edades de curado se detectan 2 señales en torno a -68 ppm y -74 ppm asociadas a unidades de $\mathrm{Si} \mathrm{Q}^{0}$ y $\mathrm{Q}^{1}$ de la escoria anhidra así como 5 señales en torno a -78 ppm, -82 ppm, -85 ppm, -92 ppm y -99 ppm asignadas a unidades de Si $\mathrm{Q}^{1}, \mathrm{Q}^{2}(1 \mathrm{Al}), \mathrm{Q}^{2}(0 \mathrm{Al}) \mathrm{Q}^{3}(1 \mathrm{Al}), \mathrm{Q}^{3}(0 \mathrm{Al})$, respectivamente, siendo estas señales características del gel $\mathrm{C}-\mathrm{S}-\mathrm{H}$ formado en pastas de escoria activada alcalinamente $(10,23)$.

El espectro de ${ }^{27} \mathrm{Al}$ RMN MAS de las pastas de cemento anhidro $100 \mathrm{C}$ presenta dos señales hacia 79 ppm y 9 ppm asociadas a las unidades de Al tetraédrico y octaédri$\mathrm{co}$, respectivamente. Las unidades de Al tetraédrico se deben a la presencia de Al en las fases silicato de spectra for the 7-day alkali-activated slag pastes were visibly different from the foregoing. At these ages two signals were detected at around -68 ppm and -74 ppm, associated with $S i Q^{0}$ and $Q^{1}$ species in the anhydrous slag, as well as five signals at around -78, -82, -85, -92 and -99 ppm, respectively assigned to Si $Q^{1}, Q^{2}(1 A l)$, $Q^{2}(O A l), Q^{3}(1 A l)$ and $Q^{3}(O A l)$ species. These signals are characteristic of the $\mathrm{CSH}$ gel formed in alkali-activated slag pastes $(10,23)$.

The ${ }^{27} \mathrm{Al}$ MAS NMR spectra for the $100 \mathrm{C}$ anhydrous cement paste had two signals, at around 79 and 9 ppm, respectively associated with tetrahedral and octahedral Al units. The tetrahedral Al units were due to the presence of $A$ l in the alite and belite silicate phases. This

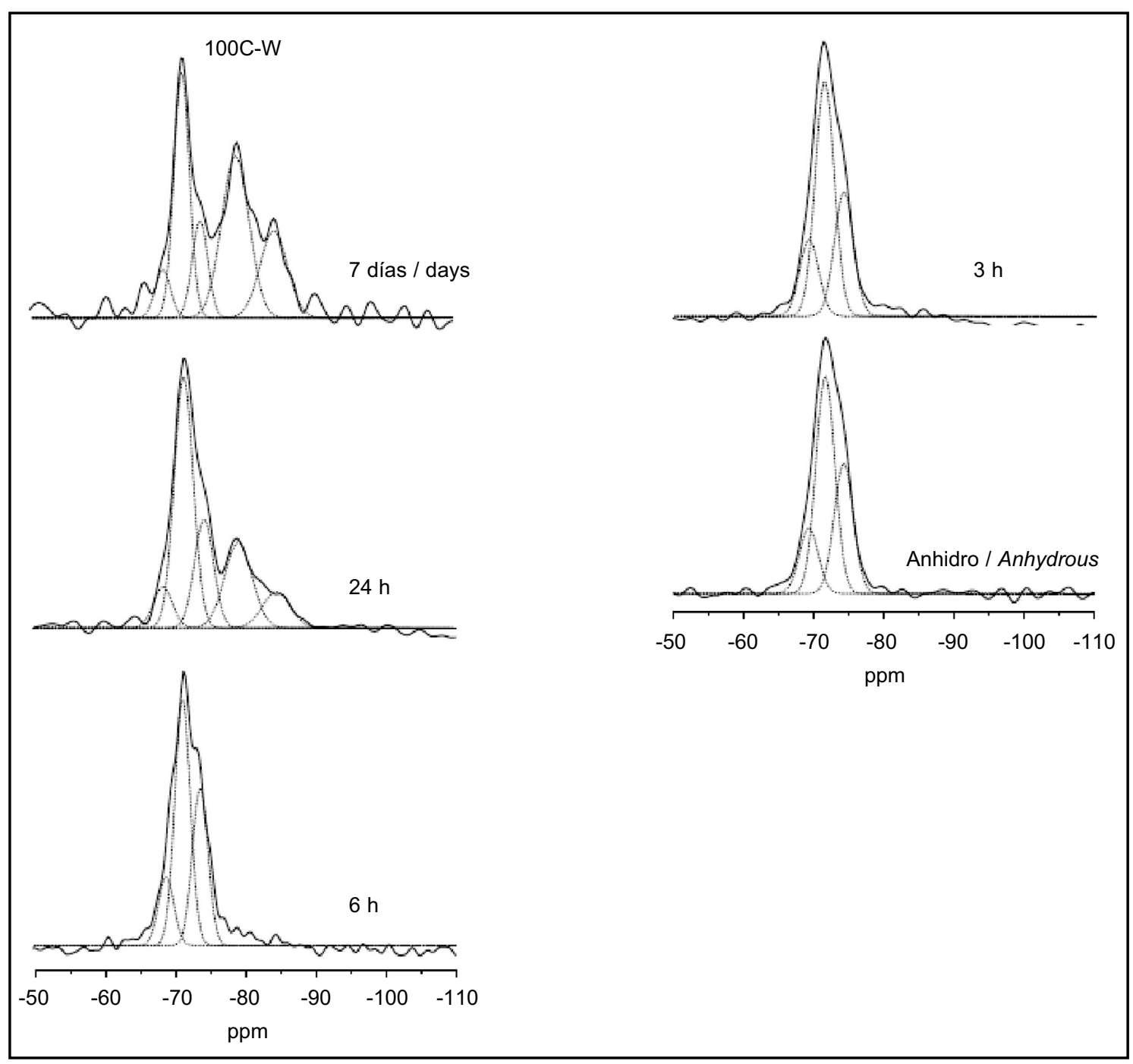

Figura 4. Espectros ${ }^{29} \mathrm{Si}$ RMN MAS $100 \mathrm{C}-\mathrm{W}$ anhidro e hidratado. Figure 4. ${ }^{29} \mathrm{Si}$ MAS NMR spectra for anhydrous and hydrated 100C-W. 
alita y belita. A su vez, esta señal tetraédrica es asociada parcialmente a la fase $\mathrm{C}_{4} \mathrm{AF}$, cuya presencia queda confirmada por la señal de Al octaédrico detectada (24-26). En el caso de las pastas de cemento hidratadas $100 \mathrm{C}$, los espectros de ${ }^{27} \mathrm{Al}$ RMN MAS muestran un descenso de la señal de Al tetraédrica a medida que se incrementa el tiempo de curado como consecuencia de la hidratación de las fases anhidras. Asimismo, a todas las edades de curado estudiadas se observa la presencia de dos señales en torno a 13,5 ppm y 9 ppm asignadas al Al octaédrico de la etringita y del monosulfoaluminato, respectivamente. Adicionalmente a 24 h y 7 días de hidratación se detecta una señal de Al octaédrico hacia 4 ppm asociada a fases aluminato hidratadas (25).

Los espectros de ${ }^{27} \mathrm{Al}$ RMN MAS de las pastas de cementos anhidros $80 \mathrm{C} 20 \mathrm{~S}$ y $70 \mathrm{C} 30 \mathrm{~S}$ son similares a los del cemento $100 \mathrm{C}$ aunque presentan junto con la tetrahedral signal was also partially associated with $C_{4} A F$, whose presence was confirmed by the octahedral Al signal detected (24-26). The 27 Al MAS NMR spectra for the hydrated $100 \mathrm{C}$ cement pastes showed a decline in the tetrahedral Al signal with curing time as a result of anhydrous phase hydration. In addition, the spectra for all the ages studied contained two signals at around 13.5 and 9 ppm, assigned to the octahedral Al in ettringite and monosulphoaluminate, respectively. The octahedral Al signal detected at around 4 ppm after 24 hours and 7 days was associated with hydrated aluminium phases (25).

The ${ }^{27} \mathrm{Al}$ MAS NMR spectra for the anhydrous $80 \mathrm{C20S}$ and 70C30S cement pastes were similar to the spectra for the $100 \mathrm{C}$ cement, although in addition to the signal

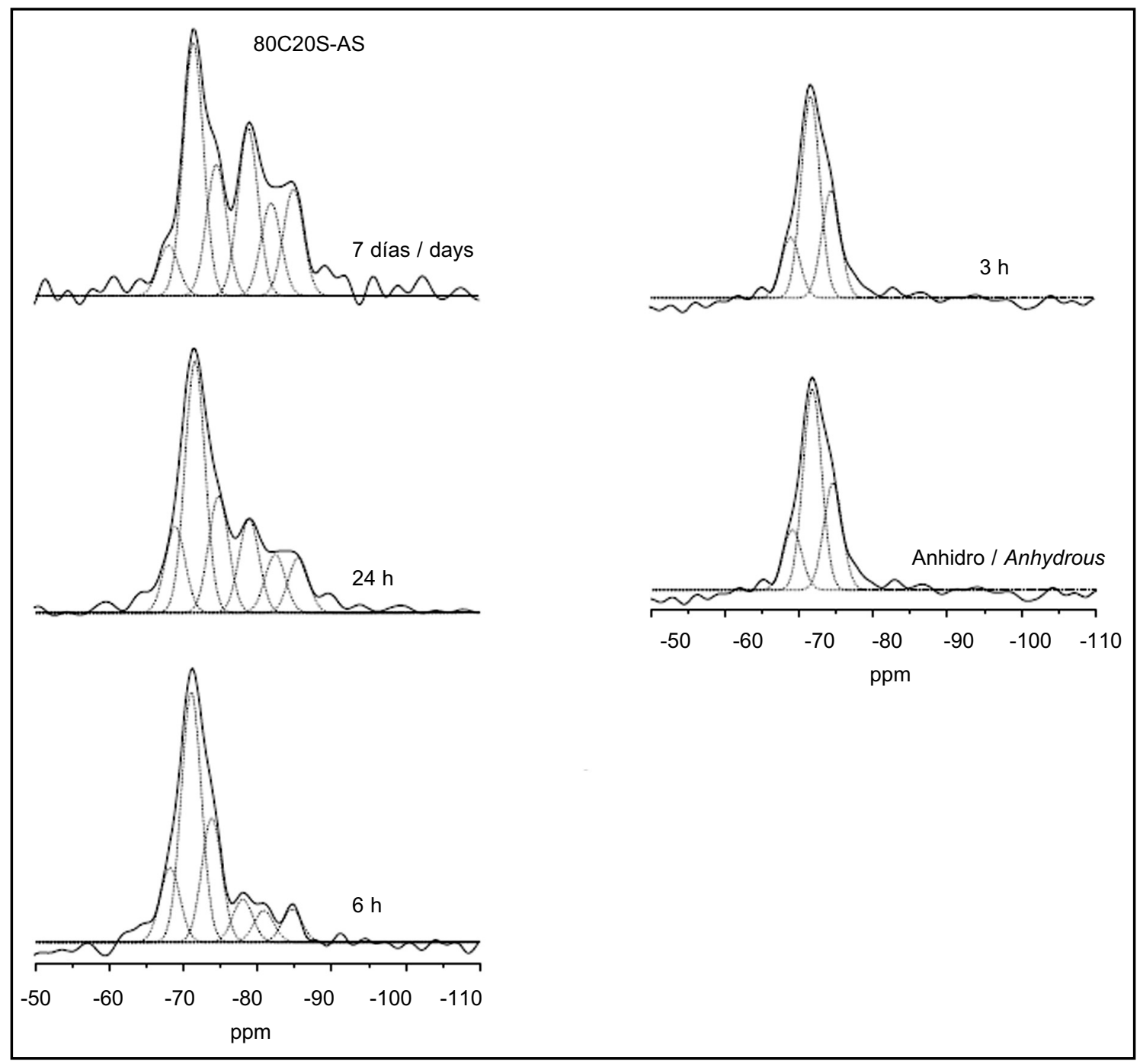

Figura 5. Espectros $29 \mathrm{Si}$ RMN MAS $80 \mathrm{C} 20 \mathrm{~S}-\mathrm{AS}$ anhidro e hidratado. Figure 5. ${ }^{29}$ Si MAS NMR spectra for anhydrous and hydrated 80C20S-AS. 
señal a 80 ppm, una señal en torno a 65 ppm asignada al Al tetraédrico de la escoria presente en ambos cementos. A medida que se incrementa el tiempo de curado, al igual que en el cemento $100 \mathrm{C}$, se observa el descenso de la señal a $80 \mathrm{ppm}$. Por el contrario, la señal a $65 \mathrm{ppm}$ se incrementa confirmando la presencia de Al sustituyendo parcialmente al Si en el gel $\mathrm{C}-\mathrm{S}-\mathrm{H}$ como ya se observó en los espectros de ${ }^{29} \mathrm{Si}$ RMN MAS. Finalmente, los espectros de ${ }^{27}$ Al RMN MAS de la escoria $100 \mathrm{~S}$ muestra únicamente una señal de Al tetraédrico en torno a 65 ppm. Asimismo, las pastas hidratadas de escoria $100 \mathrm{~S}$ presentan una señal a 65 ppm asociada a la escoria anhidra, y en el caso de las pastas hidratadas a 7 días, la señal tetraédrica también correspondería al Al incorporado al gel C-S-H. Las pastas $100 \mathrm{~S}$ hidratadas 7 días presentan adicionalmente una señal de Al octaédrico en torno a 9 ppm (14). at 80 ppm, they exhibited another at 65 ppm assigned to the tetrahedral $A$ in the slag present in these cements. As in cement 100C, the signal at 80 ppm was observed to decline at higher curing times. By contrast, the signal at 65 ppm grew, confirming the presence of Al partially replacing the $\mathrm{Si}$ in the $\mathrm{CSH}$ gel, as observed in the ${ }^{29} \mathrm{Si}$ MAS NMR spectra. Finally, the ${ }^{27}$ Al MAS NMR spectra for the anhydrous $100 S$ slag had a single tetrahedral Al signal at around 65 ppm. The 1005 hydrated pastes, in turn, had a signal at 65 ppm associated with anhydrous slag, while in the 7-day hydrated pastes the tetrahedral Al signal was also associated with the Al taken up in the $\mathrm{CSH}$ gel. In addition, the 7-day hydrated 1005 pastes exhibited an octahedral Al signal at around 9 ppm (14).

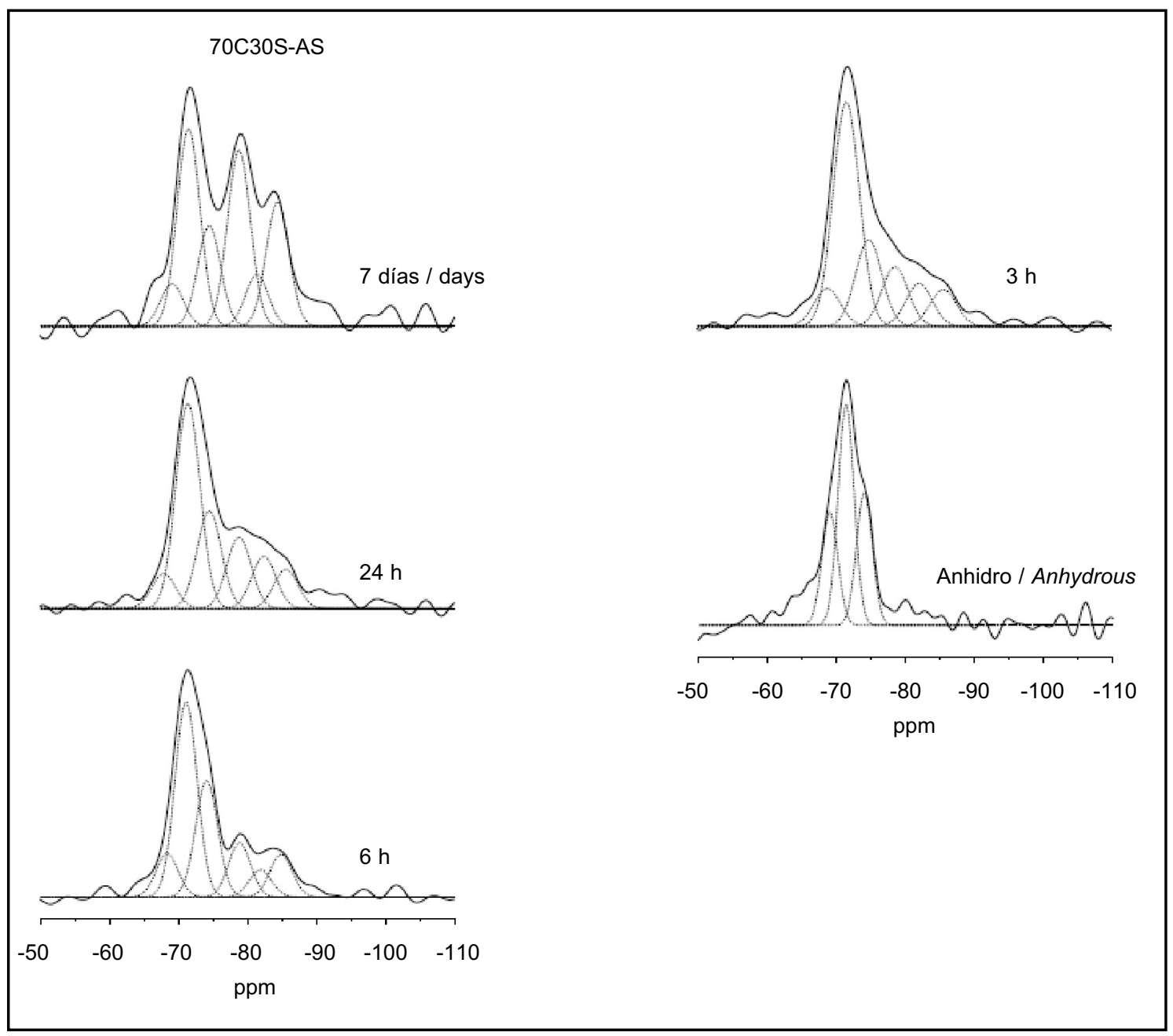

Figura 6. Espectros ${ }^{29} \mathrm{Si}$ RMN MAS de mezclas 70C30S-AS anhidra e hidratada. Figure 6. ${ }^{29}$ Si MAS NMR spectra for anhydrous and hydrated 70C30S-AS. 


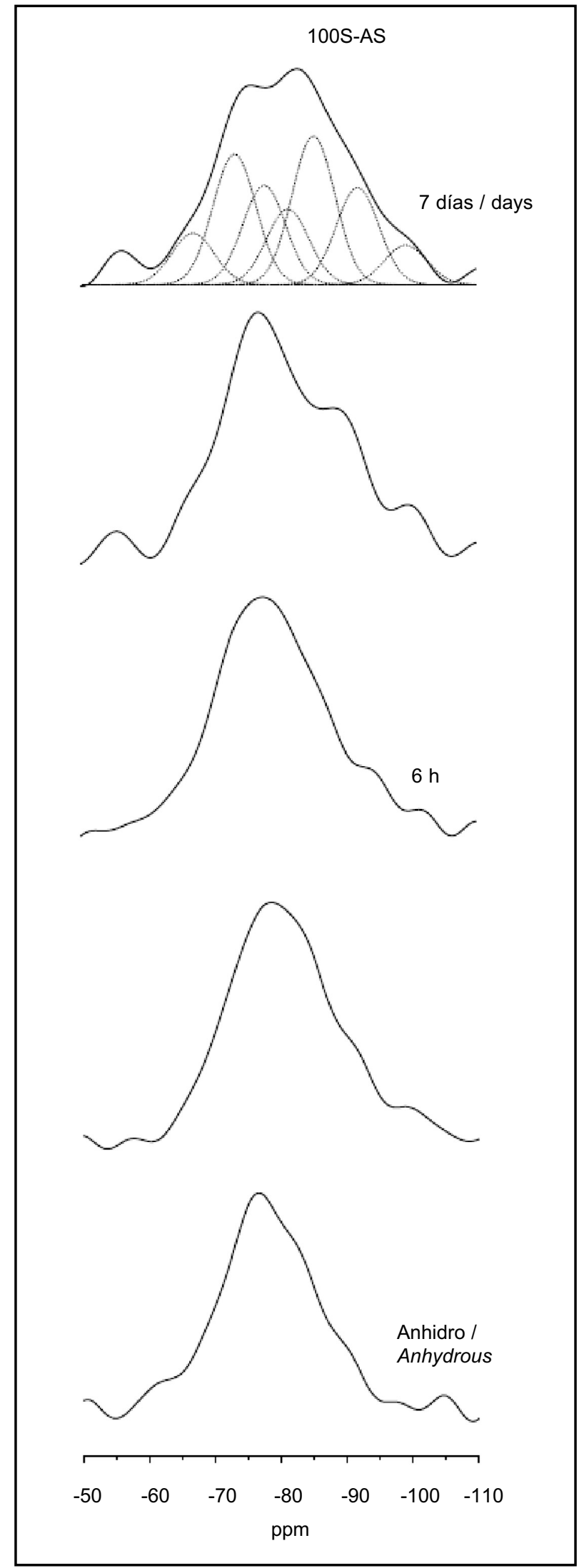

Figura 7. Espectros 27 Si RMN MAS 100S-AS anhidra e hidratada.

Figure 7. ${ }^{29}$ Si MAS NMR spectra for anhydrous and hydrated 100S-AS.

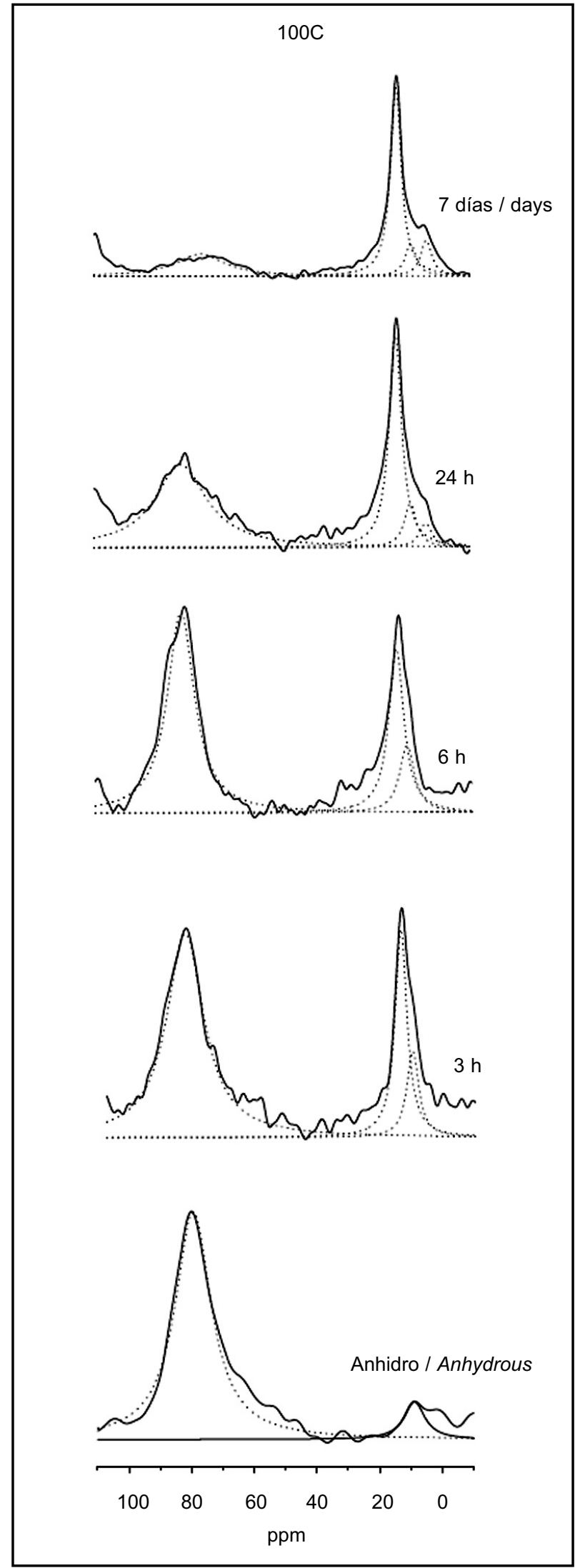

Figura 8. Espectros 27 Al RMN MAS $100 \mathrm{C}-\mathrm{W}$ anhidro e hidratado.

Figure 8. ${ }^{27}$ AI MAS NMR spectra for anhydrous and hydrated 100C-W. 

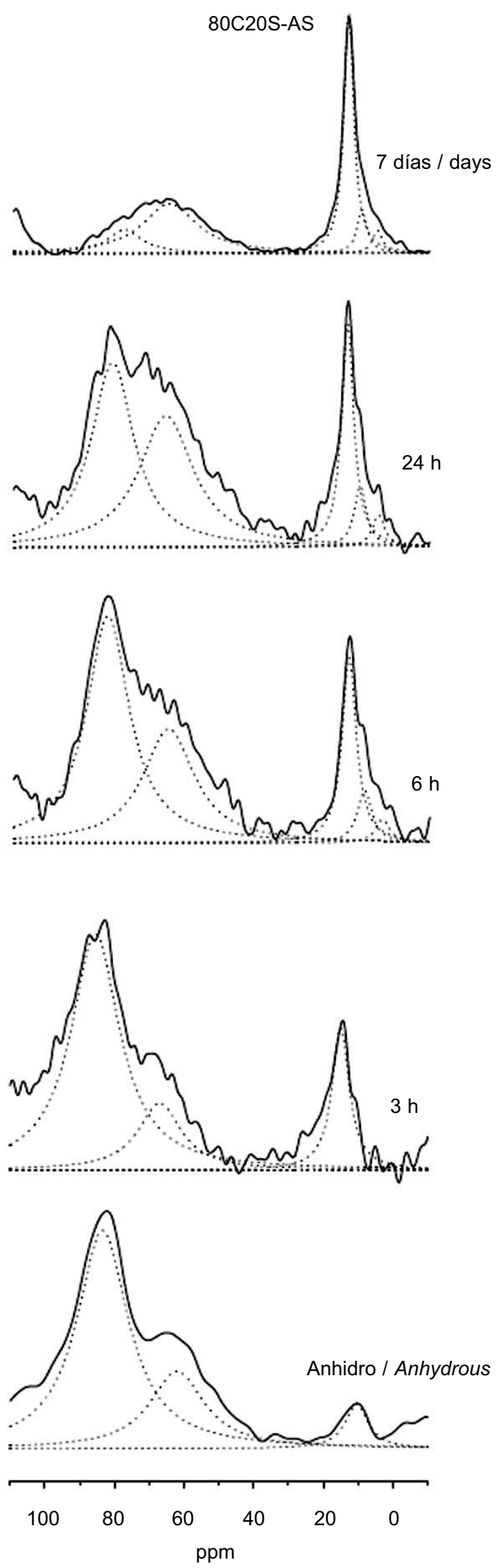

Figura 9. Espectros 27 Al RMN MAS 80C20S-AS anhidro e hidratado.

Figure 9. ${ }^{27}$ AI MAS NMR spectra for anhydrous and hydrated 80C20S-AS.

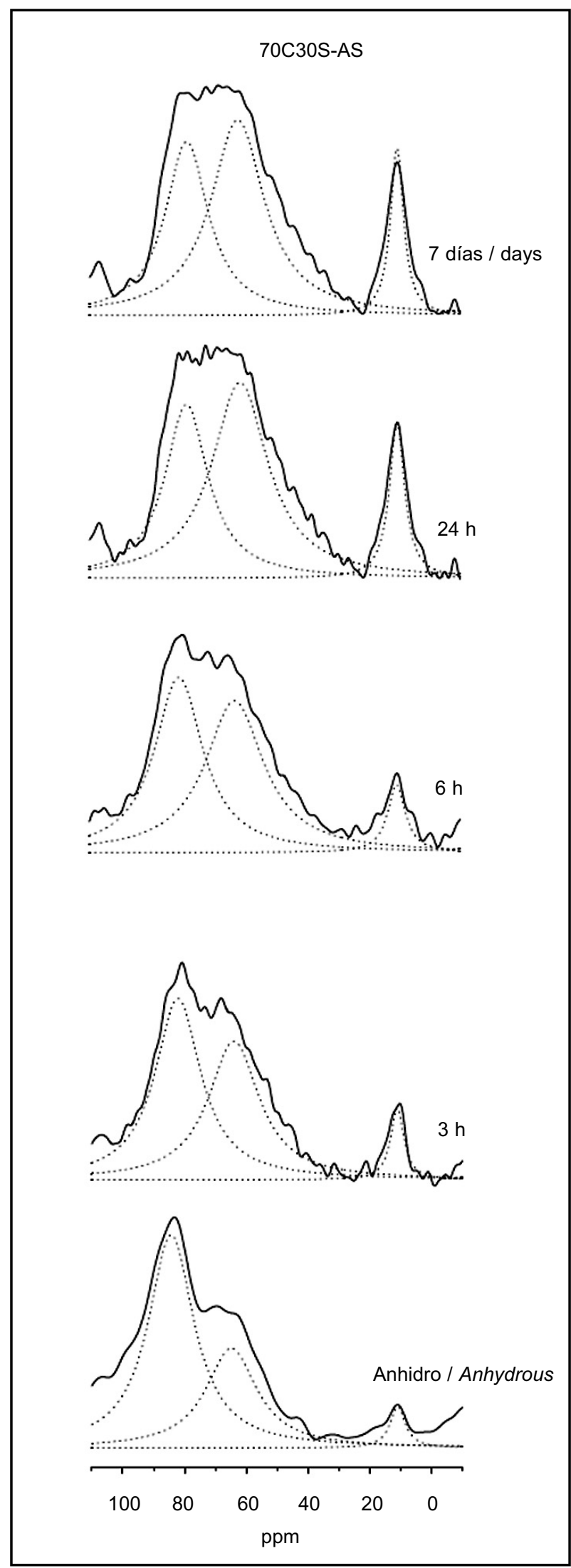

Figura 10. Espectros 27AI RMN MAS 70C30S-AS anhidro e hidratado.

Figure 10. 27AI MAS NMR spectra for anhydrous and hydrated 70C30S-AS. 


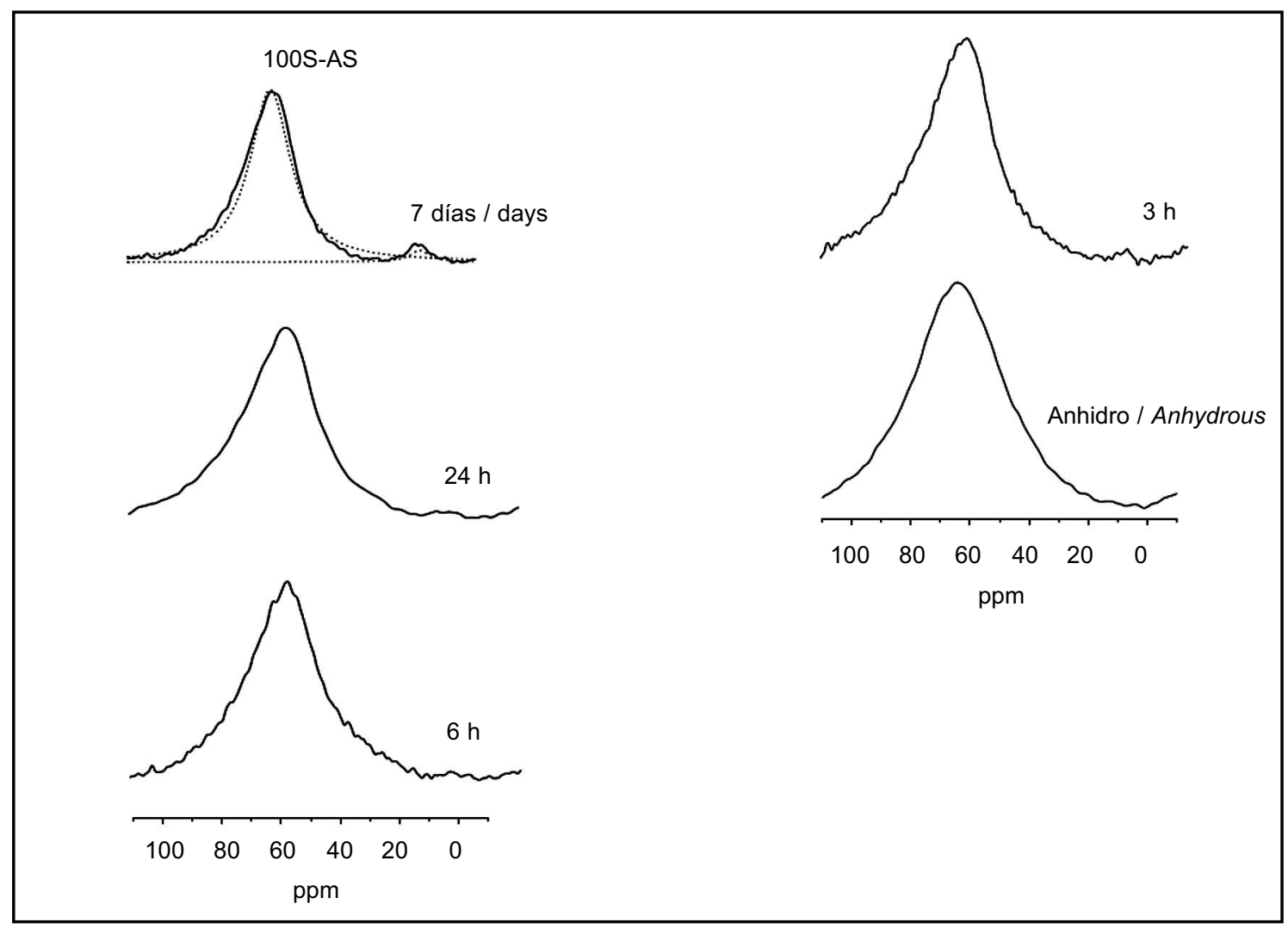

Figura 11. Espectros ${ }^{27} \mathrm{Al}$ RMN MAS 100S-AS anhidro e hidratado.

Figure 11. ${ }^{27}$ AI MAS NMR spectra for anhydrous and hydrated 100S-AS.

\subsubsection{Análisis SEM/EDX}

De las probetas ensayadas a compresión después de un curado de 28 días a $20^{\circ} \mathrm{C}$, se obtuvieron muestras que fueron analizadas por microscopia electrónica de barrido. Las probetas que contenían escoria estaban amasadas con disolución alcalina. En la Figura 12 se muestran micrografías obtenidas de cada una de las muestras.

En la muestra de cemento se observan grandes cristales de portlandita en forma de placas longitudinales. En el gel se observaron dos zonas, una muy compacta generalmente alrededor de los granos anhidros y otra más disgregada alejada de las partículas anhidras. En las lechadas de cemento-escoria la cantidad de portlandita encontrada fue menor, asimismo el gel presentaba una apariencia más fibrosa cuanto mayor era el contenido de escoria. La lechada de escoria presentó un alto grado de fisuración como consecuencia de la retracción; siendo el gel C-S-H formado muy compacto.

Estas mismas muestras fueron embutidas en resina epo$\mathrm{xi}$, pulidas y metalizadas con carbono y analizadas por microscopía electrónica de barrido de acoplado a un detector backscattered de estado sólido EDX OXFORDLINK SISTEMA ISIS (BSE /EDX). A las muestras que

\subsubsection{SEM/EDX analysis}

After the 28-day specimens cured at $20^{\circ} \mathrm{C}$ were tested for compressive strength, samples were taken and analyzed under a scanning electron microscope. The slag-containing specimens were prepared with an alkaline solution. Figure 12 shows the micrographs for one of the samples.

Longitudinal plate-like portlandite crystals were observed in the cement sample. Two distinct formations were found in the gel: a compact and a loose formation, the former generally located close to, and the latter at a distance from, the anhydrous grains. Less portlandite was found in the cement-slag slurries, and the greater the slag content, the more fibrous was the gel. The slag slurry exhibited substantial shrinkage cracking and a very compact $\mathrm{C}-\mathrm{S}-\mathrm{H}$ gel.

These same samples were sheathed in epoxy resin and carbon-coated for analysis under a scanning electron microscope coupled to an OXFORD-LINK ISIS SYSTEM, solid state backscattered electron detector (BSE/EDX). A total of 30 analyses were conducted on 

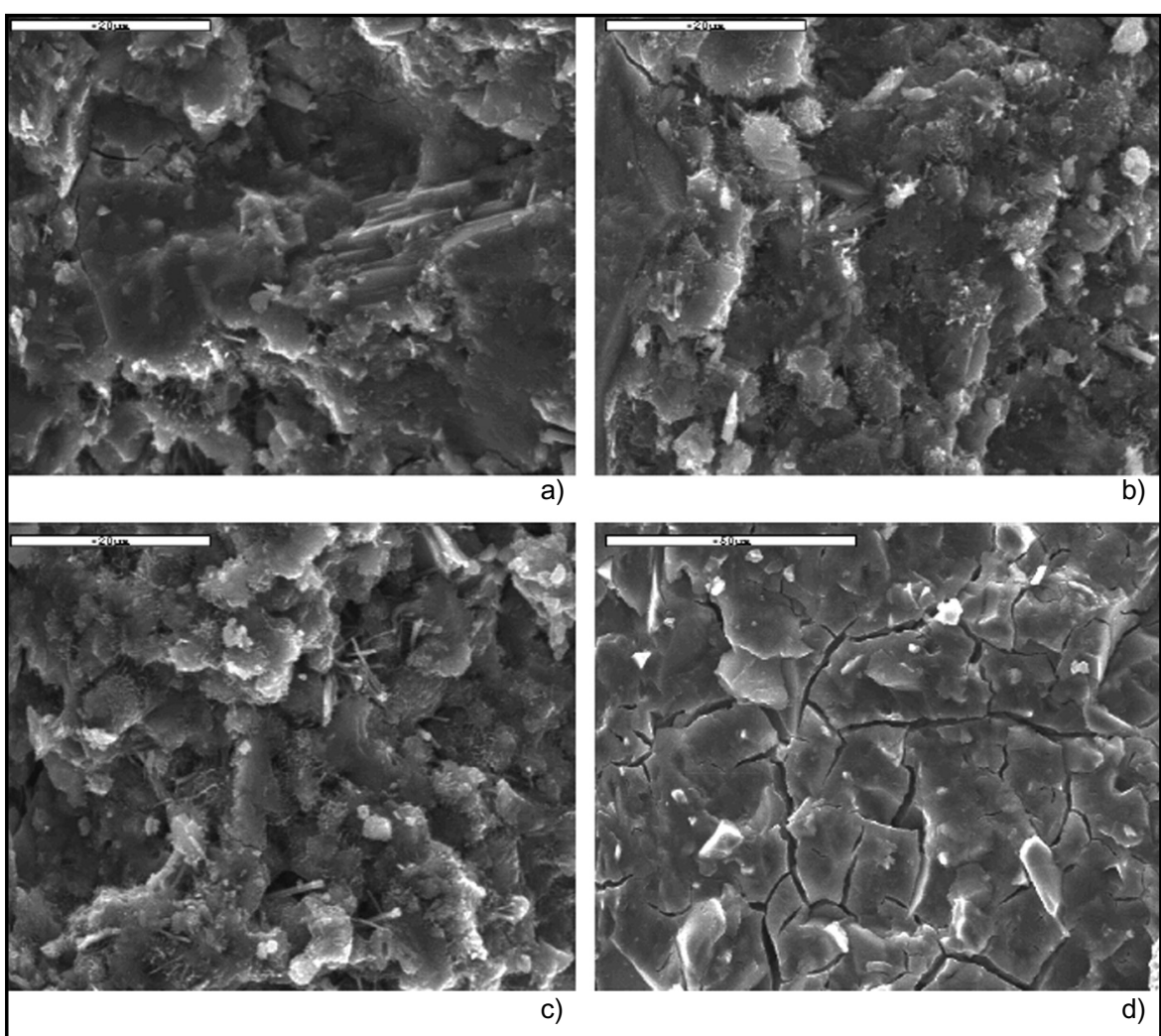

Figura 12. Micrografías obtenidas por SEM de las lechadas curadas a $20^{\circ} \mathrm{C}$ durante 28 días (a) $100 \mathrm{C}-\mathrm{W}$ a x 3.500, (b) $80 \mathrm{C} 20 \mathrm{~S}-\mathrm{AS} \times 2.000$, (c) 70C30S-AS x 2.000 y (d) $100 \mathrm{~S}-A S \times 1.000$.

Figure 12. SEM micrographs of 28-day slurries cured at $20^{\circ} \mathrm{C}$ : (a) $100 \mathrm{C}-W$ at $x 3500$, (b) 80C20S-AS at x2000, (c) 70C30S-AS at $\times 2000$, and (d) 100S-AS at $\times 1000$.

contenían cemento se le hicieron 15 análisis en la zona alrededor de los granos donde el gel se mostraba más compacto al que se denominó producto interno (Ip) y se hicieron otros 15 análisis en zonas alejadas de los granos donde el gel se observó más disgregado, denominadas producto externo (Op). A medida que se incrementaba el contenido de escoria se dificultó la localización de las zonas compactas y en su análisis químico se observaron pocas diferencias. En 100S-AS no se presentaban estas dos zonas por lo que se realizaron 30 análisis aleatoriamente. En todas las muestras se observaban granos de cemento y escoria anhidros, que se diferenciaban por ser más blancos y por su composición química (ver micrografías en la BSE en Figura 13).

La Tabla 7 muestra las relaciones atómicas promedio $\mathrm{Ca} / \mathrm{Si}, \mathrm{Al} / \mathrm{Si}, \mathrm{Al} / \mathrm{Ca}$ y $\mathrm{Na} / \mathrm{Al}$ y sus desviaciones estándar. Se observa que la relación $\mathrm{Ca} / \mathrm{Si}$ es mayor en el Op que en el Ip, sin embargo, esta relación disminuye con el incremento del contenido de escoria, hasta que a un $30 \%$ de escoria la relación es prácticamente la misma, tanto en el Ip como en el Op. Por otra parte las relaciones $\mathrm{Al} / \mathrm{Si}$ y $\mathrm{Al} / \mathrm{Ca}$ son mayores en el Op y se incrementan con el contenido de escoria tanto en el Op como en el Ip. La relación $\mathrm{Na} / \mathrm{Al}$ es mayor en el Op y disminuye con el contenido de escoria. the cement-containing samples, 15 on the inside product (Ip) or the compact gel around the grains and the other 15 on the outside (Op) or looser product. As the proportion of slag rose, it became more difficult to locate the compact areas and the differences in the respective chemical analyses narrowed. Since this distinction was not present in 100S-AS, the 30 analyses were conducted at random. Anhydrous cement and slag grains, distinguishable because of their whiter colour and chemical composition, were observed in all the samples (see BSE micrographs in Figure 13).

Table 7 shows the mean Ca/Si, Al/Si, Al/Ca and Na/Al ratios and standard deviations. The $\mathrm{Ca} / \mathrm{Si}$ ratio was observed to be higher in the outside than in the inside product. This ratio declined in the former with rising proportions of slag, however, and at a slag content of $30 \%$, it was practically the same in the inside and outside products. Moreover, the Al/Si and Al/Ca ratios were higher in the Op and grew with slag content in both the $\mathrm{Op}$ and the Ip. The $\mathrm{Na} / \mathrm{Al}$ ratio was higher in the Op, but declined with rising slag content. 


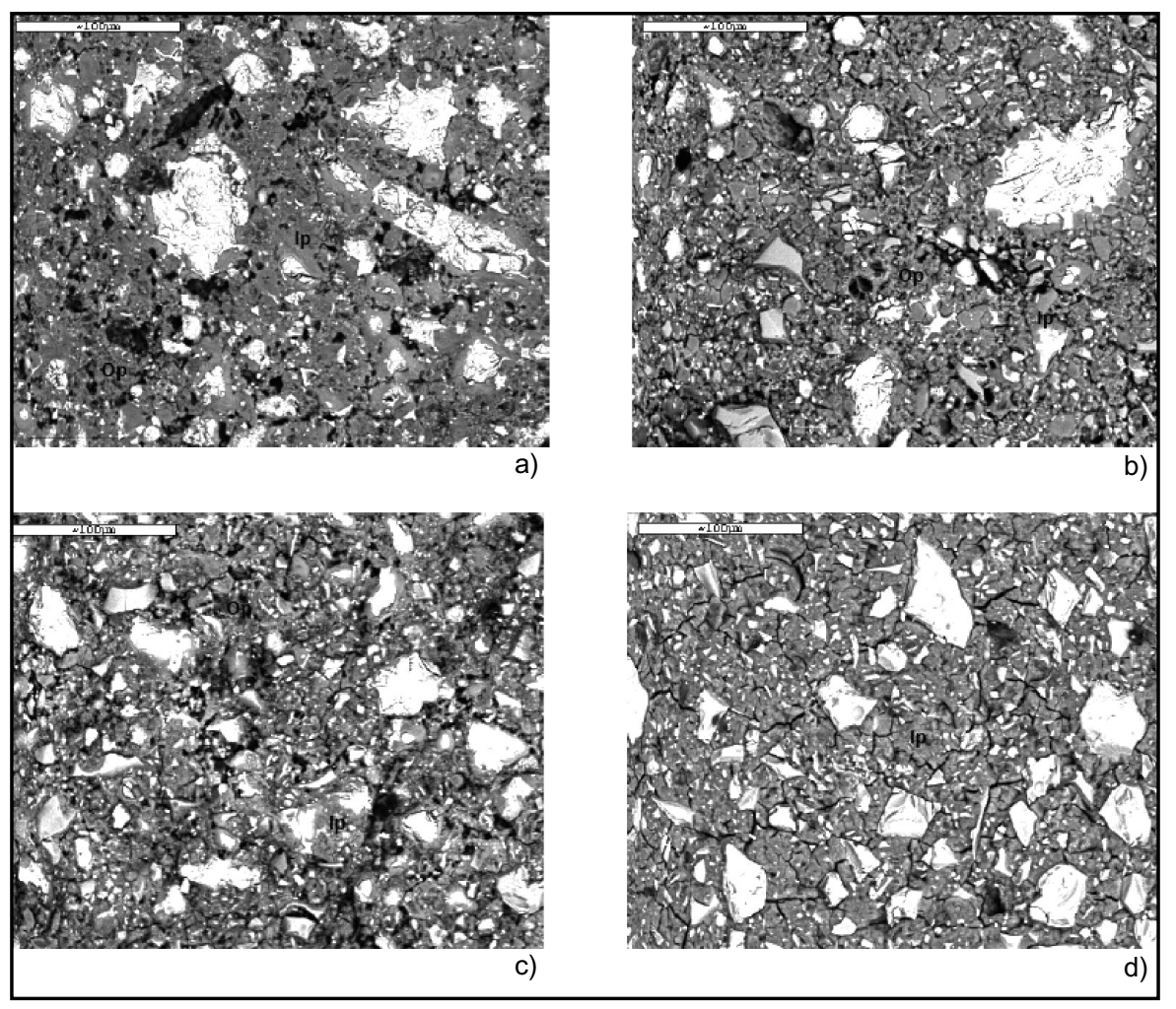

Figura 13. Micrografías obtenidas por BSE/EDX de las lechadas curadas a $20^{\circ} \mathrm{C}$ durante 28 días (a) $100 \mathrm{C}-\mathrm{W}$ a $\times 3.500$, (b) $80 \mathrm{C} 20 \mathrm{~S}-\mathrm{AS} \times 2.000$, (c) 70C30S-AS x 2.000 y (d) $100 \mathrm{~S}-\mathrm{AS} \times 1.000$.

Figure 13. BSE/EDX micrographs of 28-day slurries cured at $20^{\circ} \mathrm{C}$ : (a) 100C-W at x3500, (b) 80C20S-AS at x2000, (c) 70C30S-AS at $\times 2000$, and (d) 100S-AS at $\times 1000$.

Tabla 7 / Table 7

Relaciones atómicas.

Atomic rates.

\begin{tabular}{|c|c|c|c|c|c|c|c|c|}
\hline \multirow{2}{*}{$\begin{array}{l}\text { Lechada I } \\
\text { Slurry }\end{array}$} & \multicolumn{2}{|c|}{$\mathrm{Ca} / \mathbf{S i}$} & \multicolumn{2}{|c|}{$\mathbf{A l} / \mathbf{S i}$} & \multicolumn{2}{|c|}{$\mathrm{Al} / \mathrm{Ca}$} & \multicolumn{2}{|c|}{$\mathrm{Na} / \mathrm{Al}$} \\
\hline & Ip (13) & Op(13) & $I p(13)$ & Op(13) & Ip(13) & $O p(13)$ & Ip(13) & Op(13) \\
\hline \multirow{2}{*}{$100 \mathrm{C}-\mathrm{W}$} & 1.63 & 2.13 & 0.06 & 0.12 & 0.03 & 0.06 & 2.12 & 3.31 \\
\hline & $( \pm 0.10)$ & $( \pm 0.19)$ & $( \pm 0.01)$ & $( \pm 0.02)$ & $( \pm 0.01)$ & $( \pm 0.01)$ & $( \pm 0.72)$ & $( \pm 0.75)$ \\
\hline \multirow{2}{*}{$80 \mathrm{C} 20 \mathrm{~S}-\mathrm{AS}$} & 1.56 & 1.81 & $\begin{array}{l}0.07 \\
\end{array}$ & 0.16 & 0.05 & 0.09 & 1.14 & 1.17 \\
\hline & $( \pm 0.10)$ & $( \pm 0.20)$ & $( \pm 0.02)$ & $( \pm 0.04)$ & $( \pm 0.01)$ & $( \pm 0.01)$ & $( \pm 0.61)$ & $( \pm 0.43)$ \\
\hline \multirow{2}{*}{ 70C30S-AS } & 1.50 & 1.52 & 0.08 & 0.16 & 0.06 & 0.11 & 1.17 & 1.72 \\
\hline & $( \pm 0.15)$ & $( \pm 0.14)$ & $( \pm 0.03)$ & $( \pm 0.01)$ & $( \pm 0.02)$ & $( \pm 0.03)$ & $( \pm 0.96)$ & $( \pm 0.69)$ \\
\hline \multirow{2}{*}{ 100S-AS } & \multicolumn{2}{|c|}{0.71} & \multicolumn{2}{|c|}{0.24} & \multicolumn{2}{|c|}{0.35} & \multicolumn{2}{|c|}{0.79} \\
\hline & \multicolumn{2}{|c|}{$( \pm 0.03)$} & \multicolumn{2}{|c|}{$( \pm 0.01)$} & \multicolumn{2}{|c|}{$( \pm 0.02)$} & \multicolumn{2}{|c|}{$( \pm 0.22)$} \\
\hline
\end{tabular}

\subsection{Ensayos mecánicos}

En la Figura 14 se muestra el desarrollo de resistencias mecánicas a flexión y compresión de las probetas curadas a 2 y 28 días a $20{ }^{\circ} \mathrm{C}$. Se observa que cuando se incrementa el contenido de escoria disminuye la resistencia mecánica de las lechadas, tanto a 2 como a 28 días. Cuando las lechadas son amasadas con disolución alcalina su resistencia a edades tempranas es muy baja y aunque a mayores edades incrementan su resistencia a la compresión, no alcanzando los valores de resistencia de las lechadas amasadas con agua.

\subsection{Mechanical tests}

Figure 14 shows bending and compressive strength development in the 2- and 28-day specimens cured at $20^{\circ} \mathrm{C}$. The mechanical strength of both the 2- and the 28-day slurries was observed to decline at higher slag content values. The slurries mixed with an alkaline solution had very low early age strength, and while their compressive strength rose at older ages, it failed to reach the values found for slurries prepared with water. 


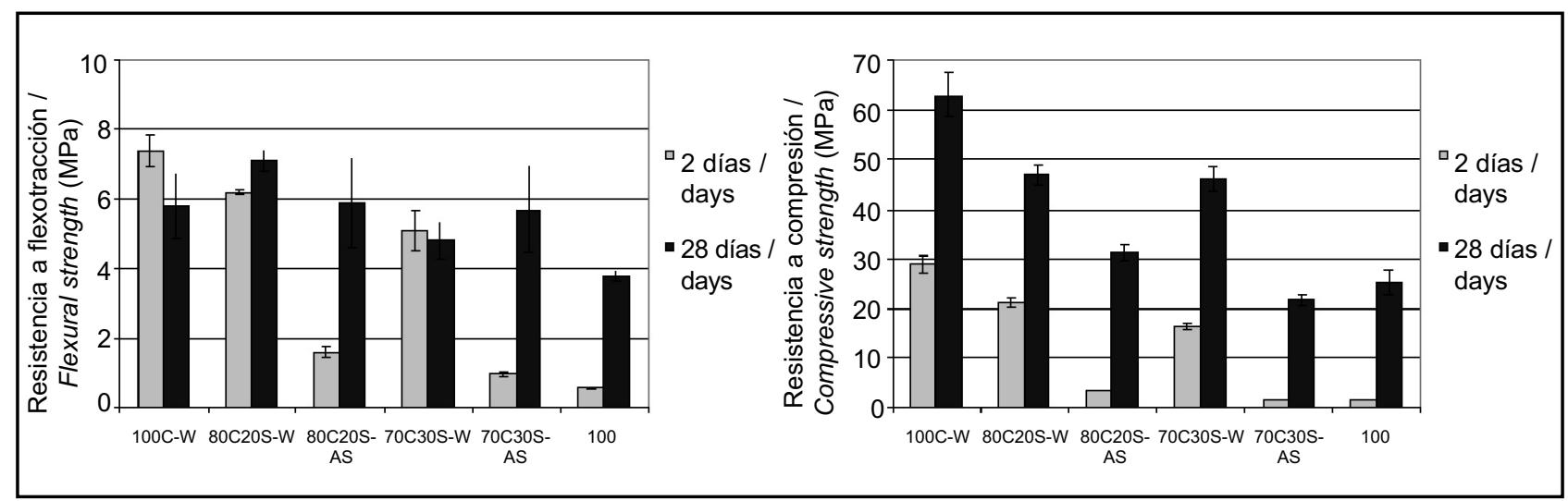

Figura 14. Resistencias mecánicas a flexión y compresión de muestras a 2 y 28 días de curado a $20{ }^{\circ} \mathrm{C}$. Figure 14. Flexural and compressive strength in 2- and 28-day samples cured at $20^{\circ} \mathrm{C}$.

El módulo elástico a compresión desarrollado por los materiales se presenta en la Tabla 8. Se observa que el módulo elástico disminuye cuando se incrementa el contenido de escoria en la mezcla haciendo la lechada más deformable. Hay que destacar las bajas resistencias mecánicas a flexión y módulo elástico que presentan las pastas de escoria activada alcalinamente. Dichas resistencias son debidas al alto grado de fisuración que experimentan las probetas por retracción.
The compressive elastic modulus developed by the materials is given in Table 8. Its value was observed to decline with rising slag content in the blend, generating a much more readily deformed slurry. The alkaliactivated slag pastes exhibited low flexural strength and elastic modulus values due to the extensive shrinkage cracking that took place in the specimens.

Tabla 8 / Table 8

Módulo de Young obtenido a 28 días de curado. Young's Modulus at 28 days of curing.

\begin{tabular}{|c|c|}
\hline Lechada / Slurry & Módulo elástico / Young's Modulus [GPa] \\
\hline 100C-W & 2.9 \\
\hline 80C20S-AS & 2.1 \\
\hline 70C30S-AS & 1.4 \\
\hline 100S-AS & 1.2 \\
\hline
\end{tabular}

\section{DISCUSIÓN DE RESULTADOS}

Los datos calorimétricos mostrados en la Tabla 4 indican que la sustitución parcial de cemento por escoria de alto horno origina un retraso de la hidratación del cemento, así como una disminución de la velocidad de precipitación de productos de reacción con respecto a aquellos cementos que carecen de esta adición. Estos resultados están de acuerdo con los obtenidos por otros autores (27). Las bajas resistencias mecánicas y módulos elásticos desarrollados por los cementos con adición de escoria (Figura 14), fundamentalmente a 2 días de curado, son una consecuencia de dicho retraso de los procesos reactivos.

Para las mezclas activadas alcalinamente (80C-20E-DA 70C30S-AS y 100S), los resultados calorimétricos obtenidos muestran que los procesos reactivos involucrados son significativamente más lentos e inducen un menor desprendimiento de calor que los mismos cementos mezclados con

\section{DISCUSSION}

The calorimetric data given in Table 4 show that the partial replacement of cement with blast furnace slag retarded cement hydration and reduced the precipitation rate of the reaction products compared to the cements lacking this addition. These results are wholly consistent with the findings reported by other authors (27). The low mechanical and yield strength developed by cements with slag additions (see Figure 14), particularly in the 2day specimens, was the result of that delay in reaction processes.

The calorimetric findings for alkali-activated cement/slag blends (80C20S-AS, 70C30S-AS and 100S) showed that the reactive processes involved were significantly slower and released less heat than in the same cements mixed with water. Furthermore, at all the ages studied, the 
agua. Asimismo, los resultados de análisis de la fase acuosa de las pastas activadas alcalinamente, (80C20S-AS y 70C30S-AS) muestran a todas las edades de curado un contenido inferior de Ca y superior en $\mathrm{Si}$ con respecto a las pastas de cemento mezcladas con agua (100C). Este menor contenido en $\mathrm{Ca}$ en la fase acuosa desde los primeros momentos de la hidratación indicaría que la disolución activadora $\left(\mathrm{Na}_{2} \mathrm{SiO}_{3} 9 \mathrm{H}_{2} \mathrm{O}\right)$ inhibe en gran parte la disolución de las fases silicato del cemento, lo cual explicaría la menor y más lenta precipitación de productos de reacción (fundamentalmente gel C-S-H y portlandita) observada mediante calorimetría de conducción. Asimismo, la concentración de Si detectada en las pastas 80C20S-AS y 70C30S-AS es significativamente inferior a la inicialmente incorporada, $0,1 \mathrm{M}$ y 0,16 M, respectivamente. Esta baja concentración de Si podría deberse a su vez a la precipitación parcial del $\mathrm{Na}_{2} \mathrm{SiO}_{3} \mathrm{OH}_{2} \mathrm{O}$ (activador alcalino) en la fase acuosa. Diferente comportamiento se puede observar en las pastas 100S-AS carentes de cemento. En este caso, el elevado pH de la disolución de silicato sódico produce la disolución de la escoria, aunque la concentración analizada de Ca en la fase acuosa es marcadamente inferior con respecto al de las pastas $100 \mathrm{C}-\mathrm{W}$ debido al menor contenido en Ca de la escoria inicial con respecto al cemento Pórtland. Además, se ha observado en la disolución acuosa de las pastas de escoria activada alcalinamente (100S-AS) la formación de un precipitado que fue analizado mediante FIIR (Figura 15). El espectro FIIR indica que corresponde a la precipitación parcial del silicato sódico empleado como activador alcalino en el seno de la fase acuosa. results of the analysis of the aqueous phase of the alkaliactivated pastes (80C20S-AS and 70C30S-AS) showed that they had visibly lower Ca and Si contents than the cement pastes mixed with water (100C). This lower Ca content in the liquid phase from the very earliest stages of hydration would indicate that the activating solution $\left(\mathrm{Na}_{2} \mathrm{SiO}_{3} \mathrm{OH}_{2} \mathrm{O}\right)$ largely inhibited dissolution of the silicate phases in the cement. That, in turn, would explain the less intense and slower precipitation of reaction products (essentially C-S-H gel and portlandite) observed with conduction calorimetry. Moreover, the Si concentration detected in pastes 80C20S-AS and 70C30S-AS was significantly lower than the $0.1 \mathrm{M}$ and $0.16 \mathrm{M}$ initially added, respectively. This low concentration of Si might be due to the partial precipitation of $\mathrm{Na}_{2} \mathrm{SiO}_{3} \mathrm{OH}_{2} \mathrm{O}$ (alkaline activator) in the aqueous phase. The cementfree 100S-AS pastes were observed to behave differently. In this case, the slag dissolved due to the high $\mathrm{pH}$ of the sodium silicate solution, although the concentration of $\mathrm{Ca}$ found in the liquid phase was substantially lower than for the $100 \mathrm{C}-W$ pastes due to the lower Ca content in the initial slag than in Portland cement. Furthermore, a precipitate detected in the aqueous solution extracted from the alkali-activated slag pastes (100S-AS) was shown by FTIR analysis to correspond to the partial precipitation in the aqueous phase of the sodium silicate used as the alkali activator (Figure 15).

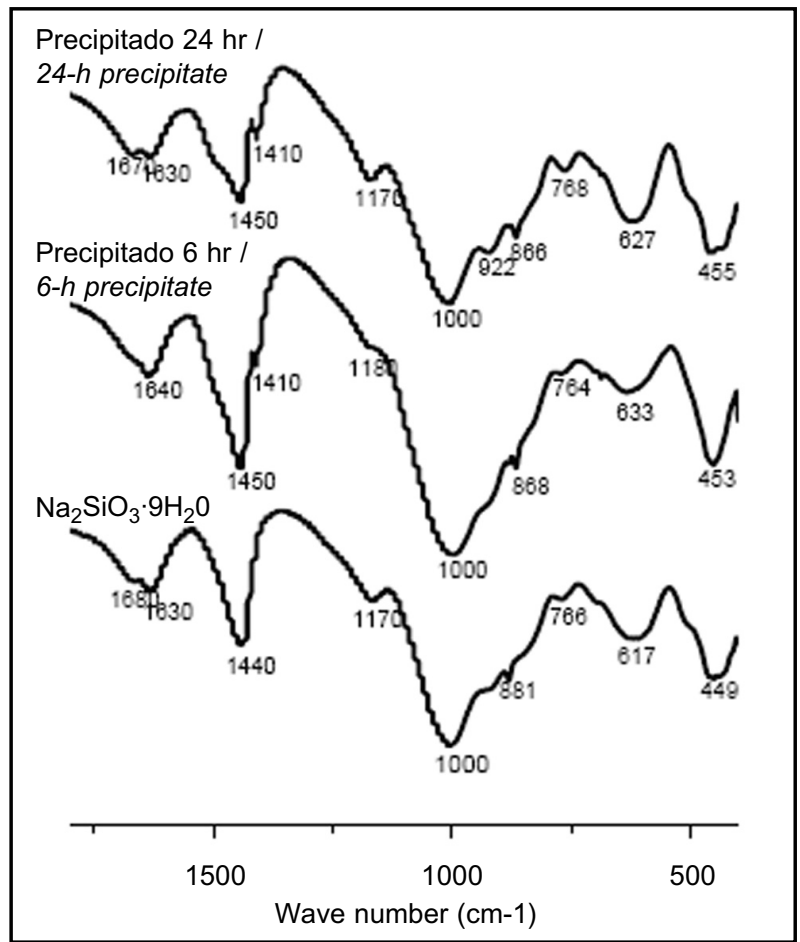

Figura 15. Espectros FIR de los precipitados encontrados en la fase acuosa de $100 \mathrm{~S}-\mathrm{AS}$ a 6 y $24 \mathrm{hr}$ comparado con el del $\mathrm{Na}_{2} \mathrm{SiO}_{3} \cdot 9 \mathrm{H}_{2} 0$. Figure 15. FTIR spectra of precipitates found in the aqueous phase of 6-and 24-hour 100S-AS pastes compared to the spectrum for $\mathrm{Na}_{2} \mathrm{SiO}_{3} \cdot 9 \mathrm{H}_{2} \mathrm{O}$. 
El estudio realizado mediante FTIR de las pastas de cemento hidratadas así como de las mezclas cemento/escoria activadas alcalinamente muestra un desplazamiento hacia valores mayores de número de onda de la banda de vibración $v_{3}(\mathrm{Si}-\mathrm{O})$ con respecto al cemento anhidro. Dicho desplazamiento indica la formación y condensación de las cadenas de silicatos del gel C-S-H a medida que aumenta el tiempo de hidratación. Estos espectros de FTIR muestran cómo en las pastas de mezcla cemento/escoria activadas alcalinamente a medida que se incrementa el porcentaje de escoria, disminuye el desplazamiento de la banda $v_{3}(\mathrm{Si}-\mathrm{O})$, confirmando nuevamente la menor hidratación del cemento Pórtland en dichas pastas activadas. Esta menor hidratación del cemento Pórtland en las mezclas cemento/escoria queda a su vez confirmada a través de los resultados de DRX, observándose un mayor contenido de fase $\mathrm{C}_{3} \mathrm{~S}$ que queda sin reaccionar en las pastas mezcla cemento/escoria con respecto a las pastas de cemento $100 \mathrm{C}$, siendo mayor el contenido de $\mathrm{C}_{3} \mathrm{~S}$ cuanto mayor es el contenido de escoria. En este mismo sentido se observa cómo la cantidad de portlandita detectada mediante FTIR y DRX disminuye al aumentar el contenido de escoria en las pastas activadas (Figura 16).
The FTIR study on hydrated cement and alkaliactivated cement/slag blended pastes showed a shift in the $v_{3}(\mathrm{Si}-\mathrm{O})$ vibration band toward higher wave numbers than recorded for the same band in anhydrous cement. That shift denotes the progressive formation and condensation of the silicate chains in the CSH gel as hydration advanced. The FTIR spectra showed that in the alkali-activated cement/slag blended pastes, the amplitude of the chemical shift for the $v_{3}(\mathrm{Si}-\mathrm{O})$ band declined with increasing percentages of slag, providing further evidence of the lesser hydration of Portland cement in the activated pastes. Such lesser Portland cement hydration in cement/slag blends was also confirmed by the XRD results, which revealed a higher unreacted $C_{3} S$ phase content in the cement/slag pastes than in cement $100 \mathrm{C}$, and higher percentages of $C_{3} S$ with rising slag contents. Similarly, the amount of portlandite detected with FTIR and XRD declined with rising proportions of slag in the activated pastes (Figure 16).

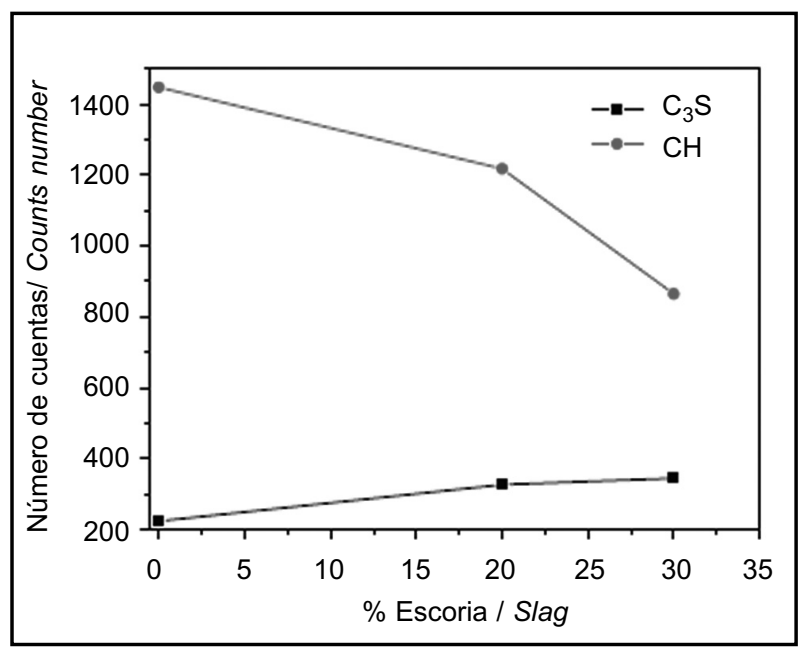

Figura 16. Cuentas obtenidas de DRX de las lechadas 100C-W, 80C20S-AS y 70C30-DA a 7 días de curado a $20{ }^{\circ} \mathrm{C}$, con respecto al porcentaje de escoria adicionado.

Figure 16. XRD counts for 7-day 100C-W, 80C20S-AS and 70C30S-AS slurries cured at $20^{\circ} \mathrm{C}$.

Los resultados discutidos indican que la presencia de la disolución activadora inhibe y retrasa la hidratación del cemento Pórtland. Dicha inhibición podría deberse al elevado $\mathrm{pH}$ del medio inducido por el silicato sódico que dificultaría la disolución de las fases silicato del cemento Pórtland. Además esta inhibición explicaría las menores resistencias mecánicas observadas de las mezclas activadas.

Los resultados de ${ }^{29} \mathrm{Si} \mathrm{y}{ }^{27} \mathrm{Al}$ RMN MAS (técnica con elevada sensibilidad para detectar los entornos del Si y Al
These findings are an indication that the activating solution inhibited and retarded Portland cement hydration. Such inhibition might be attributed to the sodium silicate-induced high $\mathrm{pH}$ in the medium, which may have hindered the dissolution of the silicate phases in Portland cement. Moreover, this inhibition would explain the lower mechanical strength observed in the activated blends.

Nonetheless, the ${ }^{29} \mathrm{Si}$ and ${ }^{27} \mathrm{Al}$ MAS NMR findings (highly sensitive to the $\mathrm{Si}$ and $\mathrm{Al}$ environments in the $\mathrm{CSH}$ gel) 
del gel C-S-H) confirman que mientras que en las pastas de cemento Pórtland mezcladas con agua se observa la formación de gel C-S-H a partir de 6 horas y 3 horas de curado, en el caso de las pastas 80C20S y 70C30S mezcladas con la disolución de silicato sódico, dicho gel C-S-H se detecta a tan sólo a las 3 horas de curado. Esto es debido a que si bien la disolución activadora inhibe la reacción del cemento Pórtland, conduciendo a la disminución de las resistencias mecánicas observadas, sí que produce la reacción de la escoria presente en las mezclas cemento/escoria produciendo gel C-S-H. Además dichos espectros muestran claras diferencias entre el gel C-S-H formado en pastas de cemento $100 \mathrm{C}$ con respecto a las de $80 \mathrm{C} 20 \mathrm{~S}$ y 70C30S. En pastas de cemento $100 \mathrm{C}$, el gel C-S-H carece de $\mathrm{Al}$ en su composición, como se puede deducir de la ausencia de unidades de $\mathrm{Si} \mathrm{Q}^{1}(1 \mathrm{Al})$ en el espectro ${ }^{29} \mathrm{Si}$ RMN MAS y de la ausencia de señales de Al tetraédrico en torno a $60 \mathrm{ppm}$ en el espectro ${ }^{27} \mathrm{Al}$ RMN MAS. Por el contrario, en las pastas de cemento/escoria activadas, el gel C-S-H contiene Al que sustituye parcialmente al Si. A su vez, de acuerdo a los resultados mostrados en la Tabla 9, la longitud media de cadena del gel C-S-H calculada de acuerdo a Richardson et al $(10,23)$, es ligeramente superior en mezclas cemento/escoria activadas (aproximadamente 5 eslabones) con respecto a pastas de cemento Pórtland $100 \mathrm{C}$ (en torno a 3 eslabones). Sin embargo, son las pastas de escoria activadas alcalinamente (carentes de cemento Pórtland) las que presentan las mayores longitudes de cadena media, presentando valores de aproximadamente 8 eslabones a edades de curado de 7 días. confirmed that while $\mathrm{CSH}$ gel forms in Portland cement pastes mixed with water after 6 and 3 hours, in the 80C20S and 70C30S pastes mixed with sodium silicate it was detected after only 3 hours. This was because the activating solution inhibited the Portland cement reaction, leading to the lower mechanical strengths observed, while the slag present in the cement/slag blends did nonetheless react, producing CSH gel. Moreover, these spectra revealed clear differences between the CSH gels forming in $100 \mathrm{C}$ pastes on the one hand and 80C20S and 70C30S pastes on the other. The $\mathrm{CSH}$ gel in cement $100 \mathrm{C}$ had no Al in its composition, as inferred by the absence of signals for both Si $Q^{1}(1 A I)$ species on the ${ }^{29}$ Si MAS NMR spectrum and tetrahedral Al (at around $60 \mathrm{ppm}$ ) on the ${ }^{27} \mathrm{Al}$ MAS NMR spectrum. The CSH gels forming in the activated cement/slag blends, on the contrary, contained Al that partially replaced Si. At the same time, pursuant to the values in Table 9, the mean chain length calculated as described by Richardson et al. $(10,23)$ was slightly greater in the activated cement/slag blended pastes (approximately five units) than in the Portland cement $100 \mathrm{C}$ materials (around three units). The longest chains were found for the cement-free alkali-activated slag, with values on the order of eight units for the 7-day specimens.

Tabla 9 / Table 9

Parámetros calculados a partir de los resultados de deconvolución mostrados en la Tabla 8 [25]. Calculated parameters from deconvolution results showed in Table 8.

\begin{tabular}{|c|c|c|c|c|}
\hline Muestra / Sample & Tiempo de curado / Curing time & $\mathbf{A l} / \mathbf{S i}$ & LMC & $\alpha$ Grado de reacción / Degree of reaction \\
\hline \multirow{4}{*}{$100 \mathrm{C}-\mathrm{W}$} & $3 \mathrm{~h}$ & - & - & - \\
\hline & $6 \mathrm{~h}$ & - & - & - \\
\hline & $24 \mathrm{~h}$ & - & 2.84 & $30.43 \%$ \\
\hline & 7 días & - & 3.07 & $53.00 \%$ \\
\hline \multirow{4}{*}{ 80C20S-AS } & $3 \mathrm{~h}$ & 0.15 & 5.00 & 20.83 \\
\hline & $6 \mathrm{~h}$ & 0.15 & 5.71 & 19.30 \\
\hline & $24 \mathrm{~h}$ & 0.22 & 5.03 & 31.40 \\
\hline & 7 días & 0.13 & 4.94 & 45.78 \\
\hline \multirow{4}{*}{ 70C30S-AS } & $3 \mathrm{~h}$ & 0.15 & 5.40 & 28.51 \\
\hline & $6 \mathrm{~h}$ & 0.11 & 5.09 & 25.90 \\
\hline & $24 \mathrm{~h}$ & 0.16 & 5.30 & 32.58 \\
\hline & 7 días & 0.07 & 4.29 & 50.86 \\
\hline \multirow{4}{*}{ 100S-AS } & $3 \mathrm{~h}$ & - & - & - \\
\hline & $6 \mathrm{~h}$ & - & - & - \\
\hline & $24 \mathrm{~h}$ & - & - & - \\
\hline & 7 días & 0.12 & 9.54 & 71.68 \\
\hline
\end{tabular}


Finalmente la disminución de la relación $\mathrm{Ca} / \mathrm{Si}$ observada mediante BSE/EDX en las pastas de cemento a medida que aumenta el contenido de escoria puede explicarse en base a varias causas. Por un lado, a la menor hidratación del cemento Pórtland en mezclas cemento/escoria activadas alcalinamente, así como a la consecuente menor precipitación de portlandita que forma una solución sólida con el gel C-S-H. Y por otro lado, la menor relación $\mathrm{Ca} / \mathrm{Si}$ observada en mezclas cemento/escoria activada debido a la formación de un gel C-S-H procedente de la activación de la escoria. Como se ha observado mediante ${ }^{29} \mathrm{Si}$ RMN MAS, dicho gel C-S-H presenta una mayor longitud de cadena y por lo tanto una menor relación en $\mathrm{Ca} / \mathrm{Si}$ que en los correspondientes cementos de escoria sin activar, estando estos resultados de acuerdo con los obtenidos en la bibliografía (13, 14, 28, 29).

\section{CONCLUSIONES}

1. La activación alcalina de mezclas cemento/escoria (con contenidos de escoria de hasta un 30\%) así como de escoria de horno alto (carentes de cemento) conducen a resistencias mecánicas significativamente inferiores a las pastas de cemento Pórtland hidratadas con agua.

2. En mezclas cemento/escoria, la disolución activadora $\left(\mathrm{Na}_{2} \mathrm{SiO}_{3} \mathrm{OH}_{2} \mathrm{O}\right)$ inhibe parcialmente la disolución de las fases silicato del cemento Pórtland originando un retraso de su hidratación así como la menor precipitación de productos de reacción. Asimismo, se observa la precipitación parcial de la disolución activadora en la fase acuosa de las pastas activadas alcalinamente.

3. Los espectros de ${ }^{29} \mathrm{Si}$ y ${ }^{27} \mathrm{Al}$ RMN MAS indican que el gel C-S-H formado en pastas de mezcla cemento/escoria activadas alcalinamente presenta una menor relación $\mathrm{Ca} / \mathrm{Si}$ que las correspondientes de cemento Pórtland hidratadas con agua. Además, se ha detectado la presencia de Al en la estructura del gel C-S-H de pastas de mezcla cemento/escoria activadas alcalinamente. Estos resultados indican que en las mezclas activadas alcalinamente de cemento/escoria, es la escoria la especie que reacciona preferentemente.

\section{AGRADECIMIENTOS}

Los autores agradecen al Ministerio español de Ciencia y Tecnología (MCyT) por la concesión del proyecto BIA BIA2007- 61380. Los autores también agradecen a A. Gil-Maroto y J. L. García su ayuda en la realización de los ensayos. M. Palacios agradece al CSIC la concesión de su contrato postdoctoral. R. Sánchez-Ramírez trabajó con una beca CONACYT (número de registro 176411).
Finally, the BSE/EDX findings showing a decline in the $\mathrm{Ca}$ /Si ratio with rising slag content were the result of two developments. On the one hand, this decline was due to the lesser hydration of Portland cement in alkaliactivated cement/slag blends, and the precipitation of concomitantly smaller amounts of the portlandite that forms a solid solution with the $\mathrm{C}-\mathrm{S}-\mathrm{H}$ gel. And on the other, it was induced by the lower $\mathrm{Ca} / \mathrm{Si}$ ratio observed in activated cement/slag blends due to the formation of a CSH gel resulting from slag activation. As the ${ }^{29} \mathrm{Si}$ MAS NMR findings showed, this CSH gel had a longer chain length and consequently a lower $\mathrm{Ca} / \mathrm{Si}$ ratio than the respective non-activated slag cements. These results concurred with data reported in the literature $(13,14$, 28, 29).

\section{CONCLUSIONS}

1. Alkali activation of cement/slag blends (with slag contents of up to $30 \%$ ) and (cement-free) blast furnace slag yields a product whose mechanical strength is significantly lower than found for water-hydrated Portland cement pastes.

2. In cement/slag blends, the activating solution $\left(\mathrm{Na}_{2} \mathrm{SiO}_{3} \mathrm{OH}_{2} \mathrm{O}\right)$ partially inhibits the dissolution of the silicate phases present in Portland cement, retarding cement hydration and reducing the precipitation of reaction products. In addition, the activating solution itself partially precipitates in the aqueous phase of the alkali-activated pastes.

3. ${ }^{29} \mathrm{Si}$ and ${ }^{27} \mathrm{Al}$ MAS NMR studies show that the CSH gel formed in alkali-activated cement/slag pastes has a lower $\mathrm{Ca} / \mathrm{Si}$ ratio than the gel forming in water-hydrated Portland cement. Furthermore, Al was detected in the structure of the $\mathrm{C}-\mathrm{S}-\mathrm{H}$ gel in alkali-activated cement/slag pastes. According to these results, in alkali-activated cement/slag blends, slag is the more reactive species.

\section{ACKNOWLEDGMENTS}

This research was funded by the Spanish Ministry of Science and Technology (MCYT) under project BIA2007-61380. The authors wish to thank A. Gil-Maroto and J.L. García for their assistance with the tests. M. Palacios participated in this research under a post-doctoral contract awarded by the Spanish National Research Council. R. Sánchez-Ramírez, in turn, participated under a Mexican National Science and Technology Council grant (registration number 176411). 


\section{BIBLIOGRAFÍA / BIBLIOGRAPHY}

(1) Taylor, H. F. W.: Cement Chemistry. 2nd Edition Thomas Telford (1997). doi:10.1680/cc.25929

(2) Nelson, E. B.: Well cementing. Elsevier Science Publishers B. V. (1990).

(3) API SPEC 10 A Twenty-third Edition, April 2002 IS0 10426-1-2001.

(4) Michaux, M.; Defosse, C.: "Oil-well cement slurries I. Microstructural approach of their rheology", Cem. and Concr. Res., 16 (1986), pp. 23-

30. doi:10.1016/0008-8846(86)90064-5

(5) Cowan, K. M.; Hale, A. H.; Nahm, J. J.: "Conversion of Drilling Fluids to Cements with Blast Furnace Slag: Performance Properties and Applications for Well Cementing", Proceedings - SPE Annual Technical Conference and Exhibition Delta (1992), pp. $277-288$.

(6) Nahm, J. J.; Romero, R. N.; Wyant, R. E.; Hale, A. A.; Briggs, B. R.; Smith, T. R.; Lombardi, M. A.; Keedy, C. R.: "Universal Fluid: A Drilling Fluid to Reduce Lost Circulation and Improve Cementing. Drilling Conference", Proceedings (1994), pp. 157-168.

(7) Mueller, D. T.; DiLullo, G.; Hibbeler, J.; Kelly, P.: "Portland cement - blast furnace slag blends in oilwell cementing applications". Proceedings - SPE Annual Technical Conference and Exhibition, Delta (1995), pp. 659-662.

(8) Salem, S.; Khelafi, H.; Kerdal, D.; Ait-Soura, S.: "Use of slags taken from blast furnaces for the improvement of petroleum cements of type G", Materials and Structures, 34 (238) (2001), pp. 253-256. doi:10.1617/13631

(9) Daulton, D. J.; Bosworth, S. J.; Pumphrey, B.; McCathy, S.; Cantu, R.: "Clendennen John. Field experience with application of blast furnace slag to the drilling and cementing program in the Stratton field, South Texas", Proceedings SPE Production Operations Symposium (1995), pp. 285-299. doi:10.2118/29472-MS

(10) Richardson, I. G.; Wilding, C. R.; Dickson, M. J.: "The hydration of blastfurnace slag cements", Advances in Cement Research, 2 (1989), pp. 147-157.

(11) Escalante, J. I.; Gómez, L. Y.; Johal, K. K.; Mendoza, G.; Mancha, H.; Méndez, J.: "Reactivity of blast-furnace slag in Portland cement blends hydrated under different conditions", Cem. Concr. Res., 31 (2001), pp. 1403-1409. doi:10.1016/S0008-8846(01)00587-7

(12) Fernández, J. A.; Puertas, F.; Arteaga, A.: "Determination of kinetic equations of alkaline activation of blast furnace slag by means of calorimetric data", Journal of thermal analysis, 52 (1998), pp. 945-955. doi:10.1023/A:1010172204297

(13) Fernández-Jiménez, A.; Puertas, F.; Sobrados, I.; Sanz, J.: "Structure of calcium silicate hydrates formed in alkaline activated slag. Influence of the type of alkaline activator", Journal of American Ceramic Society, 86 (3) (2003), pp. 1389-1394. doi:10.1111/j.11512916.2003.tb03481.x

(14) Palacios, M.: "Empleo de aditivos orgánicos en la mejora de las propiedades de cementos y morteros de escoria activada alcalinamente", Tesis Doctoral. Universidad Autónoma de Madrid (2006).

(15) Fernández-Jiménez, A.; Palomo, J. G.; Puertas, F.: "Alkali-activated slag mortars: Mechanical strength behaviour", Cem. Concr. Res., 29 (1999), pp. 1313-1321 doi:10.1016/S0008-8846(99)00154-4

(16) UNE EN 196-2:2006 Métodos de ensayo de cementos. Parte 2: Análisis químico de cementos.

(17) Barneyback, R. S.; Diamond, S.: "Expressions and analysis of pore fluids from hardened cement pastes and mortars", Cem. Concr. Res., 11 (1981), pp. 279-285 doi:10.1016/0008-8846(81)90069-7

(18) UNE EN 196-1 (1996) "Métodos de ensayo de cementos. Parte 1. Determinación de resistencias mecánicas".

(19) Shi, C.: "On the state and role of alkali's during the activation of alkali-activated slag cement", Proceedings of the 11th International Congress on the Chemistry of Cement. Durban (South Africa) (2003), pp. 2097-2105.

(20) Fernández-Jiménez A.; Puertas F.: "Setting of alkali-activated slag cement, influence of activator nature". Advances in Cement Research, 13 (2001), pp. 115-121 doi:10.1680/adcr.2001.13.3.115

(21) Vázquez, T.: Contribución al estudio de las reacciones de hidratación del cemento portland por espectroscopia infrarroja. Universidad Complutense de Madrid (1975).

(22) Nakamoto, K.: Infrared spectra of inorganic and coordination compounds. John Wiley \& Sons, Inc., New York London (1963).

(23) Richardson, I. G.: "The nature of C-S-H in hardened cements", Cem. Concr. Res. 29 (8) (1999), pp. 1131-1147. doi:10.1016/S00088846(99)00168-4

(24) Kirkpatrick, R. J.; Cong, X.: "An introduction to ${ }^{27} \mathrm{Al}$ and ${ }^{29} \mathrm{Si}$ NMR spectroscopy of cements and concretes", Ed. P.Colombet and A. Grimmer (1994), pp. 55-76.

(25) Skibsted, J.; Jakobsen, H. J.; Hall, C.: "Quantitative Aspects of 27Al MAS NMR of Calcium Aluminoferrites", Advanced Cement Based Materials, 7 (1998), pp. 57-59.doi:10.1016/S1065-7355(97)00017-5

(26) Saoût, Gwenn Le, Lécolier, É.; Rivereau, A.; Zanni, H. : "Study of oilwell cements by solid-state NMR". Comptes Rendus Chimie, 7 (3-4) (2004), pp. 383-388 doi:10.1016/j.crci.2003.10.018

(27) Lea's. Chemistry of cement and concrete. 4th Edition. Edited by Peter C. Hewkett (New York), 1998.

(28) Puertas, F.; Fernández-Jiménez, A.; Blanco-Varela, M. T.: "Pore solution in alkali-activated slag cement pastes. Relation to the composition and structure of calcium silicate hydrate", Cem. Concr. Res., 34 (2004), pp. 139-148. doi:10.1016/S0008-8846(03)00254-0

(29) Taylor, R.; Richardson, I. G.; Brydson, R. M. D.: "Composition and microstructure of 20-year-old ordinary Portland cement-ground granulated blast-furnace slag blends containing 0 to 100\% slag", Cem. Concr. Res., 40 (2010), pp. 971-983. doi:10.1016/j.cemconres.2010.02.012 